pag

Business School

WORKING PAPER SERIES

\begin{tabular}{l|l} 
Working Paper & $\begin{array}{l}\text { Equity Prices and Fundamentals: } \\
\text { a DDM-APT Mixed Approach }\end{array}$ \\
& $\begin{array}{l}\text { Fredj Jawadi } \\
\text { Georges Prat }\end{array}$
\end{tabular}

http://www.ipag.fr/fr/accueil/la-recherche/publications-WP.html

IPAG Business School

184, Boulevard Saint-Germain

75006 Paris

France

IPAG working papers are circulated for discussion and comments only. They have not been peer-reviewed and may not be reproduced without permission of the authors. 


\title{
Equity Prices and Fundamentals: a DDM-APT Mixed Approach
}

\author{
Fredj Jawadi (*) and Georges Prat $(* *)$
}

April 2015

\begin{abstract}
This paper focuses on the linkages between equity prices and fundamentals for 27 individual shares from the French stock price index (CAC40). To assess fundamental value, the traditional Dividend Discount Model (DDM) equities' valuation principle is coupled with the Portfolio Choice Theory based on the Arbitrage Pricing Theory (APT). This yields a general equity valuation relationship for which the APT determines the long-term risk premium included in the DDM. Interestingly, restrictions are less significant than in the usual approaches since the number of risk premium factors is not limited a priori by the theory. Accordingly, our empirical results point to two major findings. On the one hand, while results in the literature based on the DDM showed that fundamental value dynamics are very smooth with respect to stock price indices, our DDM-APT model reproduces both trends and major share price fluctuations. On the other hand, a simple linear Error Correction Model (ECM) highlighted a mean-reversion process of equity prices towards their fundamental values.
\end{abstract}

Résumé - Ce papier analyse le lien entre le cours des actions et les fondamentaux pour 27 sociétés du CAC40 considérées individuellement. Pour calculer la valeur fondamentale d'une action, le modèle traditionnel d'actualisation des dividendes à horizon infini est couplé avec la théorie du choix de portefeuille représentée par le modèle d'arbitrage, ce dernier permettant d'estimer la prime de risque de long terme en fonction de facteurs observables communs à tous les titres, le nombre de ces facteurs n'étant pas limité a priori. Nos résultats montrent que cette approche mixte conduit à des valeurs fondamentales reproduisant à la fois les tendances de long terme et une partie substantielle des fluctuations des cours, contrairement aux valeurs très lissée obtenus dans les contributions portant sur les indices boursiers. D’autre part, un simple modèle à correction d'erreur linéaire met en évidence un processus d'ajustement des cours sur les fondamentaux.

J.E.L. Classification: G11, G12, C58, C22

Keywords: stock valuation, equity risk premium, stock price adjustment.

(*) University of Evry, France.

(**) IPAG Business School, Paris, France, and EconomiX, CNRS, University of Paris Ouest Nanterre la Defense, 92001 Nanterre, France 


\section{Introduction}

The relationship between stock prices and fundamentals is particularly interesting as it allows us to verify the efficient-market hypothesis (Fama, 1965) and to better understand stock market dynamics. In particular, in line with the definition given by Samuelson (1965), the efficiency hypothesis implies that the spread between stock price and fundamental value is a white noise. ${ }^{1}$ Ever since the 1980s, this topic has been at the center of a large body of empirical research in the financial literature (Shiller, 1981; Campbell and Shiller, 1988; Beltratti and Shiller, 1990, etc.). Furthermore, the strong and rapid stock price run since the nineties led researchers to question the determinants of stock price valuations and to check whether this growth is due primarily to fundamentals or if it is the result of a bubble (Heaton and Lucas, 2000; Shiller, 2000; Boswijk et al. 2007, etc.). Of course, the answer to this question would be easy if fundamentals could be directly observed. However, in practice we need to estimate fundamental values by making assumptions based on representations of expectations and risk, the spread between stock price and fundamentals clearly depending on these assumptions. In fact, any estimation of fundamental value proposed in the literature is based on a particular specification of the well-known Dividend Discount Model (DDM) while studies focus on national stock price indices. ${ }^{2}$ Two important results may be noted: first, the estimated fundamental value appears very smooth compared to the stock price index; second, a dynamic process of stock price towards fundamentals is active, suggesting further evidence of mean reversion in stock prices. Consequently, a key question is whether these results are related to an aggregation issue due to stock price indices, given that indices may cause disruption in the adjustment process as some shares are overvalued while, simultaneously, others are undervalued. With respect to this question, it must be noted that studies estimating fundamental values of individual shares using time series are very scarce, while we found no study analyzing the dynamic adjustment process of equity prices towards fundamentals.

Unlike previous studies, the present paper aims to fill the present gap in the literature and to represent the fundamental values at firm level using a set of individual equities of 27 major companies belonging to the French stock price index (CAC40) over the period 19892007. Our study proposes a new approach that couples the DDM with the Arbitrage Pricing theory (APT). This allows us to link the standard principle of equity valuation with a pricing principle from portfolio choice theory according to which only non-diversifiable risk due to common factors of equity returns is paid to investors. While the DDM provides the general formula for the fundamental value, the APT allows to determine the long-term risk premium in this formula using a set of observable common factors for the equities under consideration. Accordingly, we show that, unlike the numerous aggregate approaches in the literature that only represent stock price index trends, our approach captures both trends and major fluctuations in individual equity prices. Furthermore, using an error correction model (ECM),

\footnotetext{
${ }^{1}$ A first version of this paper was presented at the "workshop on Financial Risks" in Orleans, March $4^{\text {th }} 2015$. The authors would like to thank for comments received during this event.

${ }^{2}$ For an overview of the literature on stock price indices and fundamentals' relationships, see Jawadi and Prat (2012).
} 
a mean-reversion mechanism of equity prices towards their fundamental values is identified that enhances the relevance of our approach to estimate the fundamental values.

This paper is organized as follows. Section 2 briefly reviews the related literature associated with equity price and fundamentals' relationships. Our mixed DDM-APT model is presented in section 3. The empirical results are discussed in section 4. Section 5 concludes.

\section{Brief review of the literature}

According to the general assets' valuation principle, the value of any asset is given by the sum of its discounted future cash flows. Concerning equities, cash flows are given by dividends, and this leads to the DDM whose expressions differ greatly depending on the representation of expectation and risk. We first relate the contributions conducted at aggregate level that refer to the determination of the stock price index. We then examine the contributions devoted to the determination equity prices that are made at the level of the firm. These surveys helped to motivate our choice in the current study to represent the fundamental value of an equity.

\subsection{Stock price indices and fundamentals}

The literature includes many studies, all of them referring to the infinite time horizon DDM to determine the fundamental value of a national stock price index. ${ }^{3}$ These studies show that deviations between stock price indices and fundamentals are often large and durable, both under the rational expectation hypothesis (REH) and using the Gordon-Shapiro formula with simplifying hypotheses representing the discount rate and the expected dividend growth rate (Shiller, 1981; Campbell and Shiller, 2001; Allen and Yang, 2001; Manzan, 2003; Boswijk et al., 2007). These deviations are explained in different ways: e.g., as irrational fads (Shiller, 1981; Summer, 1986), overconfidence (Daniel et al., 1998), behavioral heterogeneity (Barberis and Thaler, 2003; Manzan, 2003; Boswijk et al., 2007), information asymmetry and mimetic behavior (Poterba and Summers, 1988; Fama and French, 1988; Cecchetti et al., 1990; Barberis et al., 1998; Jawadi, 2006), as well as arbitrage costs including transaction costs and a premium that reflects the uncertainty characterizing the appraisal of fundamental value (Jawadi and Prat, 2012). Furthermore, acording to these related contributions, the adjustment process of stock price indices toward fundamentals is often found to be asymmetrical and nonlinear. It is worth noting that all of these studies showed that the estimated fundamental values are relatively smooth compared to the stock market indices. ${ }^{4}$

\footnotetext{
${ }^{3}$ We leave aside portfolio choice theories based on the international CAPM or international-APT where national stock market returns are considered from the perspective of building an efficient world portfolio. Studies generally focus on modeling the time-varying degree of integration of national stock markets and gains from international diversification. The empirical results show that international variables play a part in determining national market risk premium (in particular the return on the world stock index).

${ }^{4}$ However, by introducing a time-varying risk premium in the Gordon-Shapiro formula, Prat (1992, 2013) showed that it is possible to generate a fundamental value of the S\&P index, which is more volatile than that obtained under REH. However, the author did not analyze the stock price adjustment towards the fundamental value.
} 
The measurement of stock price deviations is of course conditional on the assumptions underlying the estimation of the fundamental value, and in particular those regarding measures of expectations and risk. In fact, the above-mentioned studies refer to the DDM with representations of expectations based on relatively strong hypotheses such as REH or constant values for the expected growth rate of dividends and discount rate, the latter including the risk-free rate and the risk premium. All studies consider an infinite time horizon. In particular, using REH, the DDM deduced from Lucas' (1978) inter-temporal consumption-based asset pricing model leads to a fundamental value corresponding to Shiller's "rational ex-post price” (Shiller, 1981). This approach led Shiller to raise the socalled "volatility puzzle", meaning that stock market price is far more volatile than that predicted by fundamental value. Moreover, Mehra and Prescott (1985) introduced the socalled "equity premium puzzle", meaning that, with reasonable values of risk aversion and time preference coefficients, Lucas' model leads to a theoretical equity risk premium which is much lower than the observed market values. Many contributions have attempted to solve these two puzzles. ${ }^{5}$ Interestingly, Cechetti et al. (2000) showed that, in contrast to the REH, the introduction of distorted expectations in the consumption-based asset pricing DDM model helped to solve both the "volatility puzzle" and the "equity risk premium" puzzle. To justify the distorted expectations hypothesis, the authors argue that "individuals find it too costly to acquire the skills to do maximum-likelihood." Accordingly, agents tend to use a less accurate but cheaper prediction method: "instead, they respond by using rules of thumb". Using expected stock returns from the S\&P index deduced from Livingston's expert survey, Park (2006) identified biases similar to those supposed by Cechetti et al. (2000), and thus confirmed that distorted expectations can solve the equity premium puzzle. Also using Livingston's S\&P expectation data, Abou and Prat (2000) showed that experts adopt rules of thumb such as the traditional extrapolative, regressive or adaptive expectations processes, while Prat (2007) showed that S\&P index dynamics are pretty much in accordance with the consumption-based asset pricing model when using Livingston's distorted expectations, contrary to results when adopting the REH. Fama and French (2002) calculated ex-ante premia on the US stock market using the Gordon-Shapiro DDM formula by assuming that both the risk-free rate and the expected dividend growth rate are given by the historical averages of interest rate and dividend growth rate respectively. As a result, the authors found a long-term premium of around $2.5 \%$ per annum on average during the period extending from 1951 to 2000, the 'observed' value approaching that predicted by the consumption-based asset-pricing model. This suggests that it is relevant to measure long-term ex-ante risk premium using the DDM to compare it to some theoretical value.

\subsection{Equity prices and fundamentals at firm level}

The DDM was first applied to equities by Williams (1938) and then widely used by financial analysts, notably after the publication of the famous Gordon-Shapiro formula, especially for an infinite time horizon (Gordon-Shapiro, 1956; Gorgon, 1962). Supposing various plausible values of the DDM components (i.e. investment time horizon, expected

\footnotetext{
${ }^{5}$ Kocherlakota (1996) and more recently Prat (2007) provided comprehensive literature surveys of the equity premium puzzle.
} 
dividend growth rate, discount rate), Bates (1962) built tables giving the corresponding theoretical share values. Although these tables help analysts in their decision-making, there is no attempt to optimize the values of the DDM components to best represent equity prices. To do this, further studies applied econometrical approaches and showed that the DDM explains a significant part of equity prices. The authors either considered cross-section data between firms (Gordon, 1959; Whitbeck and Kisor, 1963; Malkiel and Cragg, 1982) ${ }^{6}$ or individual time series (Lorie and Hamilton, 1973; Booth, 1998; Foerster and Sapp, 2005). Efthimios et al., (2004) confirmed that the valuation practices of financial analysts are very often based on formula derived from the DDM. In fact, there are very few DDM econometrical approaches based on time series, and papers by Booth (1998) and Foerster and Sapp (2005, F\&S hereafter) are among the exceptions. Interestingly, in line with Booth - who estimated the Gordon formula for a sample of six Canadian telecommunications companies from 1966 to 1995 - F\&S focused on the Bank of Montreal share price, which is one of the most preeminent banks in North America, and which consistently paid regular dividends from 1882 to 2003. F\&S compared the relevance of two DDM formulas: i) a finite time-horizon formula with perfect foresight for future dividends and price, and ii) the well-known Gordon infinite time-horizon formula $F=D /(r-g)$, where $F, D, r$ and $g$ denote fundamental value, dividend, discount rate and dividend growth rate, respectively. In both approaches, the discount rate is given by the CAPM where coefficient beta is arbitrary set at 1 (without explanation); in other words, the discount rate equals the riskless rate (yield on government bonds) plus the expected market risk premium defined as the expected market returns less the government bond yield, where expected returns are calculated using a rolling window from past value of returns on the U.S. stock market. It is worth noting that this risk premium determination hypothesis implies that portfolio choice theory - according to which only the non-diversifiable risk is paid to investors - is combined with DDM to determine the fundamental value. For the second model, the authors followed Booth (1998), assuming that the expected dividend growth rate is determined by a linear combination of GNP growth and inflation. Surprisingly, this rate does not depend on the observed values of the dividends growth rate. The results showed that the Gordon formula leads to better representation of share price than the finite time-horizon formula with perfect foresight. Otherwise, although the Gordon formula explains the long-term equity price trend, fluctuations are relatively poorly described. ${ }^{7}$ It is also worth noting that, to our knowledge, none of the micro-level approaches using the DDM analyze the dynamic adjustment process of equity prices towards fundamentals.

Another approach to equity price factors is of course given by portfolio choice theory. In fact, since the 1970s, empirical studies involving individual share prices have concentrated on Sharpe's (1964) Capital Asset Pricing Model (CAPM) and, to a lesser extent, the Arbitrage Price Theory (APT) by Ross (1976). These two asset pricing models do not deal with the concept of fundamental value but focus on determining equity risk premia under the

\footnotetext{
${ }^{6}$ For each of the five years covering the period 1961-1965, the authors showed that between $50 \%$ and $75 \%$ of variance in the observed price/earnings ratios of 175 American firms can be explained by the DDM components wherein the beta coefficients (deduced from the CAPM) are considered a risk indicator. For a given firm, this means that the risk premium is given by beta times the regression coefficient. As a result, this approach is a mixture of the DDM and a simple version of the CAPM.

${ }^{7}$ Note that F\&S also showed that the dividends-based model outperforms the earnings-based model.
} 
hypothesis that only non-diversifiable risk due to common factors must be paid to investors since they can build efficient portfolios which eliminate specific risk. While the CAPM implies that only the market factor is relevant, the APT does not limit the number of common factors a priori. ${ }^{8}$ To sum up, the APT appears to be fairly satisfactory in explaining crosssectional stock return differences and seems to explain some of the pricing anomalies relative to the CAPM. ${ }^{9}$ Assuming constant coefficients beta and risk premia, empirical studies on the APT using cross-sectional regressions identify the significant common macroeconomic returns factors : production or consumption growth rates, inflation, term and default spread of interest rates, oil price, exchange rates and stock market returns appeared to be the more relevant factors (among others, see Roll and Ross, 1980; Chen et al. 1986; Fontaine, 1987; Elton et al., 1994). Interestingly, using a conditional APT specification where both the beta coefficients and the risk premia for each factor are time-varying, Kryzanowski et al., 1997) confirmed that such macroeconomic factors are relevant to explain time-varying equity premia.

Overall, several lessons can be drawn from the reported literature on stock price indices and individual equity prices vis-à-vis fundamentals. First, the representation of fundamental equity values is always deduced from a DDM specification, either for firms or for stock price indices. Second, for all specifications, the dynamics of the estimated fundamental values appear to be smooth compared to stock price, this result depending of course on the assumptions made to specify the DDM, especially the REH or the constant dividend growth rate and discount rate hypotheses. However, the REH seems to result in a poorer representation of stock price than non-rational expectations. Third, at aggregate level, the adjustment of stock price indices towards fundamentals is found to be delayed and often nonlinear. This could possibly be due to the fact that some securities may be overvalued while, at the same time, others may be undervalued, which can disrupt the adjustment process when considering market indices. In this respect, there is no study to our knowledge on the dynamic adjustment process of individual equity prices towards fundamentals. To fill this gap, we propose considering individual equities rather than indices. Unlike stock price indices and as suggested by portfolio choice theory, the valuation of an equity price raises the question of the linkage between the equity and common factors. To this end, we assume that long-term investors hold efficient portfolios, as supposed in a few studies representing the DDM risk premium by referring to the CAPM. However, in line with empirical results from the APT, we will consider a large set of macroeconomic variables to represent the relevant common factors of the DDM long term premia, including the market factor suggested by the CAPM. This yields our DDM-APT mixed approach.

\section{The DDM-APT mixed approach}

While the DDM fundamental value of an equity is defined as the present value of the sum of expected dividends over an infinite time-horizon, the APT determines the long termy risk premium to be included in the DDM by a limited set of common equity factors. Formally, let $r_{\text {ot }}$ be the risk-free rate, $\varphi_{i t}$ the long-term risk premium of equity $i$ and $\tilde{g}_{i t}$ the long-term expected rate of dividend growth at time $t$. Supposing that, as a rule of thumb due to cognitive capacity and to information costs, stockholders consider these variables

\footnotetext{
${ }^{8}$ See Section 3 for more details on the APT approach

${ }^{9}$ In particular, see Chapter 5 by Barucci (2003) that gives an overview of the empirical results arising from the two asset-pricing models.
} 
monotonically between $t$ and all the successive periods $t+k$, the fundamental value $F_{i t}$ of an equity $i$ (dividends and rates are expressed in annual basis) corresponds to the following wellknown "Gordon-Shapiro" formula ${ }^{10}$ :

$$
\begin{aligned}
& F_{i t}= \frac{\bar{D}_{i t}}{r_{o t}+\varphi_{i t}-\tilde{g}_{i t}} \quad \text { with } \quad r_{o t}+\varphi_{i t}-\tilde{g}_{i t}>0 \quad i=1, \ldots, n \\
& \bar{D}_{i t} \text { are smoothed dividends, } \\
& r_{o t} \text { is the risk-free discount rate, } \\
& \tilde{g}_{i t} \text { is the long-term expected dividend growth rate, } \\
& \varphi_{i t} \text { is the long-term risk premium. }
\end{aligned}
$$

Accordingly, the fundamental value depends on four variables: i) dividends, ii) riskfree rate, iii) expected dividend growth rate, and iv) risk premium. First, the amount of dividends $D_{i t}$ that are paid to holders of equity $i$ is known; however, since payments are irregular, ${ }^{11}$ we considered the smoothed value noted $\bar{D}_{i t}=\exp \left(\overline{\log D_{i t}}\right)$, where $\overline{\log D_{i t}}$ is the Hodrick-Prescott filter value $(H P)$ of $\log D_{i t}$. This enables us to remove the dividend jumps; moreover, this seems consistent with the long-term horizon characterizing the fundamental value. Second, the risk-free discount rate $r_{o t}$ is measured by the trend of an appropriate longterm guaranteed interest rate (French government bonds yield). Although there is a priori no default risk in this yield, consideration of this trend enables us to eliminate the market risk and liquidity premia representing short-term components of government bonds yield. It is thus not surprising that considering the HP trend rather than observed yield improved the empirical results. Third, the expected long-term rate of growth in dividends $\tilde{g}_{i t}$ is assumed to follow a simple regressive process: ${ }^{12}$

$$
\tilde{g}_{i t}-\bar{g}_{i t}=\lambda_{i}\left(g_{o i}-\bar{g}_{i t}\right)
$$

where:

$\bar{g}_{i t}$ is the long-term dividend growth rate calculated perceived at time t, calculated as $\bar{g}_{i t}=\log \left(\bar{D}_{i t} / \bar{D}_{i t-1}\right)$, with $\log \bar{D}_{i t}$ as the Hodrick-Prescott filter trend of $\log D_{i t}$

$g_{o i}$ is the constant "normal value" of the dividend growth rate ${ }^{13}$ (will be included in a composite intercept in the whole model)

\footnotetext{
${ }^{10}$ This formula is deduced from a continuous-time framework.

${ }^{11}$ Unlike aggregate dividends associated with stock price indices, the monthly time series of dividends follows stepped patterns for any given firm.

${ }^{12}$ With respect to the traditional regressive expectation process, the observed rate of growth $g_{i t}$ was here replaced by the long- term rate $\bar{g}_{i t}$ assumed to be perceived by investors.

${ }^{13}$ This value can be viewed as characterizing the dynamic equilibrium condition regarding dividends growth.
} 


\section{$\lambda_{i}$ is a behavioural expectation parameter to be estimated}

According to the "rule of thumb” (2), if $\lambda_{i}>0, \widetilde{g}_{i t}$ converges towards the normal value $g_{o i}$, while if $\lambda_{i}<0$ is negative, the divergence between $\widetilde{g}_{i t}$ and $g_{o i}$ is expected to increase. The case $\lambda_{1}=0$ implies that the expected long-term growth rate $\tilde{g}_{i t}$ equals the perceived longterm rate $\bar{g}_{i t}$, while the case $\lambda_{i}=1$ implies that $\tilde{g}_{i t}$ equals the normal value $g_{o i}$. It can be noted that if equation (2) is augmented with some common factors representing the influence of the macroeconomic environment of firms, and if such factors are among those that determine the risk premium (see next paragraph), then our final estimation of the fundamental value would remain unchanged. This remark suggests that, for the model as a whole, the expected rate determination can be considered broader than it appears at first sight with equation (2).

Concerning the risk premia $\varphi_{i t}$, in line with the APT, long-term investors are supposed to hold efficient portfolios. We should recall that the APT is based on two general hypotheses: i) at any time, the condition of no-arbitrage opportunity prevails on the market, implying that with null initial wealth, any riskless investment leads to a zero expected return, ${ }^{14}$ ii) the return $R_{i t}$ of any risky asset $i$ includes three elements: (a) the expected return of the equity for the investment $\widetilde{R}_{i t}$, (b) the unexpected return of equity $i$, which depends linearly on the unexpected values of $k$ independent common factors $j X_{t}(j=1, \ldots, k)$; these factors are supposed common knowledge among investors with sensitivities ${ }_{j} \beta_{i}$ whose sign depends on the equity for a given factor, and (c) the unexpected return resulting from the unexpected specific factors. As a result of these hypotheses, the risk premium of any risky asset $\varphi_{i t}$ can be expressed as a linear combination of the $k$ sensitivities ${ }_{j} \beta_{i}$ to common factors:

$$
\varphi_{i t}=\sum_{j=1}^{k}{ }_{j} \beta_{i}{ }_{j} \varphi_{t}
$$

where ${ }_{j} \varphi_{t}$ is the risk premium that would prevail if only the common factor ${ }_{j} X_{t}$ was involved with a sensitivity of ${ }_{j} \beta_{i}=1$. According to (3), only the systematic risk due to common factors is paid since specific factors can be removed using diversification. ${ }^{15}$ When

\footnotetext{
${ }^{14}$ This condition means that the purchase of securities is offset by short sales. Interestingly, the absence of the arbitrage hypothesis is in accordance with Welch (2000) who showed that investors have a strong view in favor of this condition. Otherwise, using experts' individual risk premia deduced from the Livingston surveys that give the expected value of the S\&P industrial index, Abou and Prat (2010) identified common factors driving the dynamics of these premia in the APT framework. These factors include expected inflation and expected GNP growth rates that are given by the same survey.

${ }^{15}$ If the only common factor is the domestic stock market, the risk premia of equities given by equation (3) correspond to the CAPM; this case is characterized by ${ }_{1} \varphi_{t}=\widetilde{R}_{m t}-r_{o t}$, where $\widetilde{R}_{m t}$ stands for the expected market return and ${ }_{j} \varphi_{t}=0 \forall j, t$ for $j \neq 1$.
} 
components ${ }_{j} \varphi_{t}$ are assumed to be steady over time, they are usually estimated in two steps for the $n$ equities: i) the first step consists of regressing (time series) each of the $n$ observed one-period returns on a set of the zero-mean unexpected components of $k$ common variables and possibly changes in their expected values (typically, an ARIMA model is used to estimate the one-period ahead expected value): the slopes of these regressions give the estimated values of the sensitivities ${ }_{j} \beta_{i}(i=1, \ldots, n ; j=1, \ldots, k)$ while the intercepts represent the expected returns of the equities, ${ }^{16}$ ii) the second step consists of regressing (cross-section) the $n$ expected returns on the estimated values of ${ }_{j} \beta_{i}$, the premia then being given by the values of the slopes, while the riskless rate is captured by the intercept of this regression. Accordingly, the significant common factors are those for which the slopes are significant, the risk premium of any equity $i$ being finally measured by cumulating the effects of the $k$ independent factors. However, our empirical approach differs from the usual approach in two ways. First, since relation (3) is valid whatever the value of the investment horizon, we assume that the infinite time horizon is representative of the long-term horizon. Second, in accordance with equations (1) and (2), the DDM provides a measurement per date of the longterm expected excess returns so it becomes possible to search for common factors directly, hence allowing us to estimate straight the long-term risk premia $\varphi_{i t}$ to be paid to investors. For this purpose, each component ${ }_{j} \varphi_{t}(j=1, \ldots k)$ of $\varphi_{i t}$ is assumed to be linearly related to the observable common factor ${ }_{j} X_{t}$, i.e. ${ }_{j} \varphi_{t}={ }_{j} a{ }_{j} X_{t}+{ }_{j} b$ where the expected signs of coefficients ${ }_{j} a$ are generally rather intuitive. ${ }^{17}$ The common factors ${ }_{j} X_{t}$ are not a priori identified by the theory but a posteriori by empirical analysis. To do this, let $P_{i t}$ be the market equity price for a given firm $i(i=1, \ldots, n)$ at time $t$. The condition of $P_{i t}=F_{i t}$ in the DDM formula (1) combined with the APT hypotheses on the risk premia determination lead to the two following expressions of the long-term expected excess return $\tilde{\delta}_{i t}$ of any equity $i$ :

$$
\tilde{\delta}_{i t}=\frac{\bar{D}_{i t}}{P_{i t}}+\tilde{g}_{i t}-r_{0 t}=\sum_{j=1}^{k}{ }_{j} \gamma_{i j} X_{t}+\sum_{j=1}^{k}{ }_{j} \alpha_{i}+\eta_{i t}
$$

\footnotetext{
${ }^{16}$ A preliminary factor analysis applied to the unexpected components and possibly changes in the expectations of observable variables is often used in this first stage to choose the $k$ common factors of returns. Of course, this approach does not avoid the arbitrary choice in the initial set of common variables considered; note that it involves a methodological choice since several statistical techniques may be used a priori.

${ }^{17}$ Regarding the seven significant common factors ${ }_{j} X_{t}$ considered hereafter, for ${ }_{1} X_{t}$ (domestic stock market) and ${ }_{5} X_{t}$ (world stock market), we have ${ }_{j} a=1$ (and ${ }_{j} b=0$ ) since these factors are directly viewed as market and world risk premia respectively; for ${ }_{2} X_{t}$ (economic sentiment), we have ${ }_{j} a<0$ for ${ }_{3} X_{t}$ and ${ }_{4} X_{t}$ (interest rate spreads) and for ${ }_{6} X_{t}$ (oil price) we have ${ }_{j} a>0$; for ${ }_{7} X_{t}$ ( Euro/USD exchange rate), the sign of ${ }_{j} a$ is $a$ priori undetermined since this variable both increases the cost of imports (negative effect) and improves competitiveness (positive effect), so that the overall effect might vary according to the companies.
} 
with ${ }_{j} \gamma_{i}={ }_{j} \beta_{i}{ }_{j} a,{ }_{j} \alpha_{i}={ }_{j} \beta_{i} b$, where $\eta_{i t}$ represents diversifiable and therefore unpaid idiosyncratic stochastic factors. The left-hand expression of $\tilde{\delta}_{i t}$ represents the DDM side while the right-hand one represents the APT side. Since only the non-diversifiable risk due to common factors is paid, only these factors determine the long-term risk premium $\varphi_{i t}=\sum_{j=1}^{k}{ }_{j} \gamma_{i} X_{t}+\sum_{j=1}^{k}{ }_{j} \alpha_{i}$ in the denominator of the $F_{i t}$ formula. Accordingly, as long as the $k$ common factors ${ }_{j} X_{t}$ of the expected excess returns $\tilde{\delta}_{i t}$ are not identified in (4), the excess return $\tilde{\delta}_{i t}$ remains inoperative to determine the risk premium $\varphi_{i t}$. To determine the relevant linear combination of common factors, the expected rate $\tilde{g}_{i t}$ given by equation (2) is reported in equation (4) and we get the following relationship:

$$
\frac{\bar{D}_{i t}}{F_{i t}}-r_{o t}=\left(\lambda_{i}-1\right) \bar{g}_{i t}-\lambda_{i} g_{i 0}+\sum_{j=1}^{k}{ }_{j} \gamma_{i j} X_{t}+\sum_{j=1}^{k}{ }_{j} \alpha_{i}+\eta_{i t}
$$

Let $\theta_{i}=\lambda_{i}-1$ and $c_{i}=\sum_{j=1}^{k}{ }_{j} \alpha_{i}-\lambda_{i} g_{0 i}$ a composite intercept capturing the structural influences of the $k$ common factors on the risk premium of equity $i$, the normal value of the rate of growth in dividends $g_{o i}$ and the arbitrary calibrations of the mean of the common factors. Adding an error-term $\zeta_{i t}$ to the specific component $\eta_{i t}$, equation (5) leads to the following reduced econometric equation:

$$
\frac{\bar{D}_{i t}}{P_{i t}}-r_{o t}=\theta_{i} \bar{g}_{i t}+\sum_{j=1}^{k}{ }_{j} \gamma_{i j} X_{t}+c_{i}+\varepsilon_{i t}
$$

where $\varepsilon_{i t}=\eta_{i t}+\zeta_{i t}$.

The relationship (6) does not seek to validate or invalidate the APT represented by equation (3), especially as the expected long-term excess return $\tilde{\delta}_{i t}$ is determined conditionally to the retained specification of the DDM. In fact, equation (6) represents a joint hypothesis of the DDM (equation 1) of the expected growth rate $\tilde{g}_{i t}$ (equation 2) and of the APT (equation 3), provided that a simple and stable linear relationship prevails between each premium component ${ }_{j} \varphi_{t}$ and the set of common variables ${ }_{j} X_{t}$. As only the nondiversifiable risk is remunerable, equation (6) allows us to estimate jointly the difference $\left(\varphi_{i t}-\tilde{g}_{i t}\right)$ between the long-term risk premium and the expected long-term dividend growth rate as:

$$
\left(\varphi_{i t}-\tilde{g}_{i t}\right)^{*}=\hat{\theta}_{i} \bar{g}_{i t}+\sum_{j=1}^{k}{ }_{j} \hat{\gamma}_{i j} X_{t}+\widehat{c}_{i}
$$

where $\wedge$ stands for the estimated coefficients. The estimated value of the composite coefficient ${ }_{j} \gamma_{i}={ }_{j} \beta_{i j} a$ may a priori take any sign, as is the case for the ${ }_{j} \beta_{i}$, and the same for the estimated values of intercepts $c_{i}$. 
Next, including (7) in (1), the DDM-APT fundamental value for any equity $i$ is calculated as:

$$
F_{i t}^{*}=\frac{\bar{D}_{i t}}{r_{o t}+\left(\varphi_{i t}-\tilde{g}_{i t}\right)^{*}} \quad \text { with } \quad r_{o t}+\left(\varphi_{i t}-\tilde{g}_{i t}\right)^{*}>0
$$

\section{Empirical analysis}

\subsection{Data and preliminary analysis}

Our study considers individual equities quoted on the French stock market and belonging to the CAC40 stock price index. With regard to the availability of data over a sufficiently long period for a significant number of firms, we selected 27 equities over the period 1989-2007 ( $i=1, \ldots ., 27$ ), corresponding to the largest capitalizations. ${ }^{18}$ The October 1987 crash is therefore excluded from our sample. Furthermore, since our aim is to estimate a structural model, data covering the strong and lasting financial crisis that began in summer 2007 with the US subprime crisis were also excluded from the sample since this crisis - which is exogenous to our model - can be considered as having severely disrupted the stock market. Although the subprime crisis began in July, most of the share prices considered began their decline in the autumn (see figure 3). ${ }^{19}$ Furthermore, the absence of such major stock market crises increases the plausibility of the assumption of stability made for the coefficients in equation (6). For this reason, the approximately 18-year period of our analysis may be viewed as a compromise between the need to consider a period long enough to allow for reliable identification of common factors and the necessity for the period to be short enough to expect stable parameters. However, our sample includes the bursting of the so-called "dot.com bubble” in March 2001, which lasted about two years. This period can be viewed as a time of price adjustment to the fundamentals for firms concerned with information technology (e.g. Vivendi), enabling us to test price adjustment towards the fundamentals. Accordingly, we considered 224 monthly observations from February 1989 to September 2007 for each company under consideration.

The 27 companies included belong to various economic sectors with significant international activities: Accor (hotels), Air France (transportation), Air Liquide (gas and healthcare industry services), Alcatel (telecommunications), Axa (insurance), Bouygues (construction and telecommunications), Capgémini (consulting and IT services), Carrefour (retail), Danone (food), Essilor (ophthalmic and optical equipment), Lafarge (cement and concrete), L'Oreal (cosmetics), LVMH (luxury goods), Michelin (tyres), Pernod Ricard (wines and spirits), Peugeot (car production), PPR (woodwork, building materials, distribution; this firm was renamed Kering in 2013), Publicis (communications, advertising),

\footnotetext{
${ }^{18}$ However, some important companies were excluded either because i) data on dividends was not available for this period, or ii) these companies were subject to a merger or acquisition (i.e. EADS, EDF/GDF), or iii) the companies were listed on the stock market after 1989.

${ }^{19}$ It can be seen that the French market factor in Figure 2 confirms this point.
} 
Saint-Gobain (materials, habitat), Sanofi (pharmaceuticals), Schneider (energy efficiency, buildings security), Société Générale (banking and finance), Suez (energy and environment), Total (gas and oil extraction and refining), Unibail (promotion and property management of large shopping centers), Vallourec (seamless steel tube production) and Vivendi (communications, entertainment, news technologies). This selection gave us an exhaustive sample reflecting the French stock market. All data were obtained from Datastream.

The data relating to these firms $i$ refers to the closing equity market price $P_{i t}$ and the dividends per share paid by the company over the last year $D_{i t}$, with both variables expressed in Euros. Figure 1 reports the time series of the dividend yield $\bar{D}_{i t} / P_{i t}$ for each company in our sample and the estimated long-term perceived dividend growth rate $\bar{g}_{i t}$ (equation 2). Interestingly, we can see that the levels and dynamics are highly disparate for all $27\left(\bar{D}_{i t} / P_{i t}\right)$. Thus, the main aim of equation (6) is to analyse to what extent disparities in the $\theta_{i} \bar{g}_{i t}$ (representing the influence of specific dividend growth), in the coefficients ${ }_{j} \gamma_{i}$ (specific sensitivities to common factors) and in the composite intercepts $C_{i}$ could explain the disparities in the $\bar{D}_{i t} / P_{i t}$.

\section{Figure 1 - Dividend yields and long-term dividend growth rates}
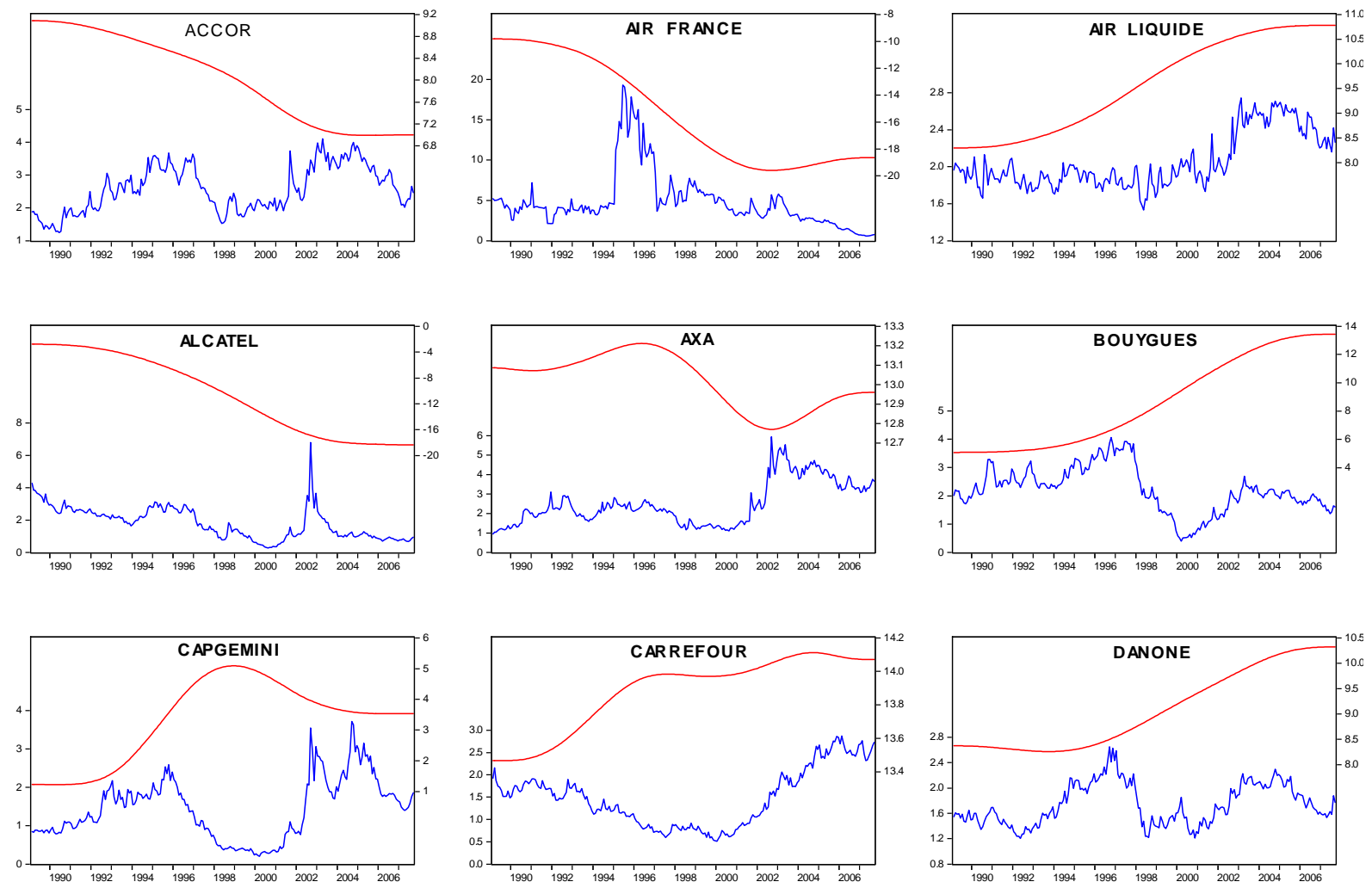

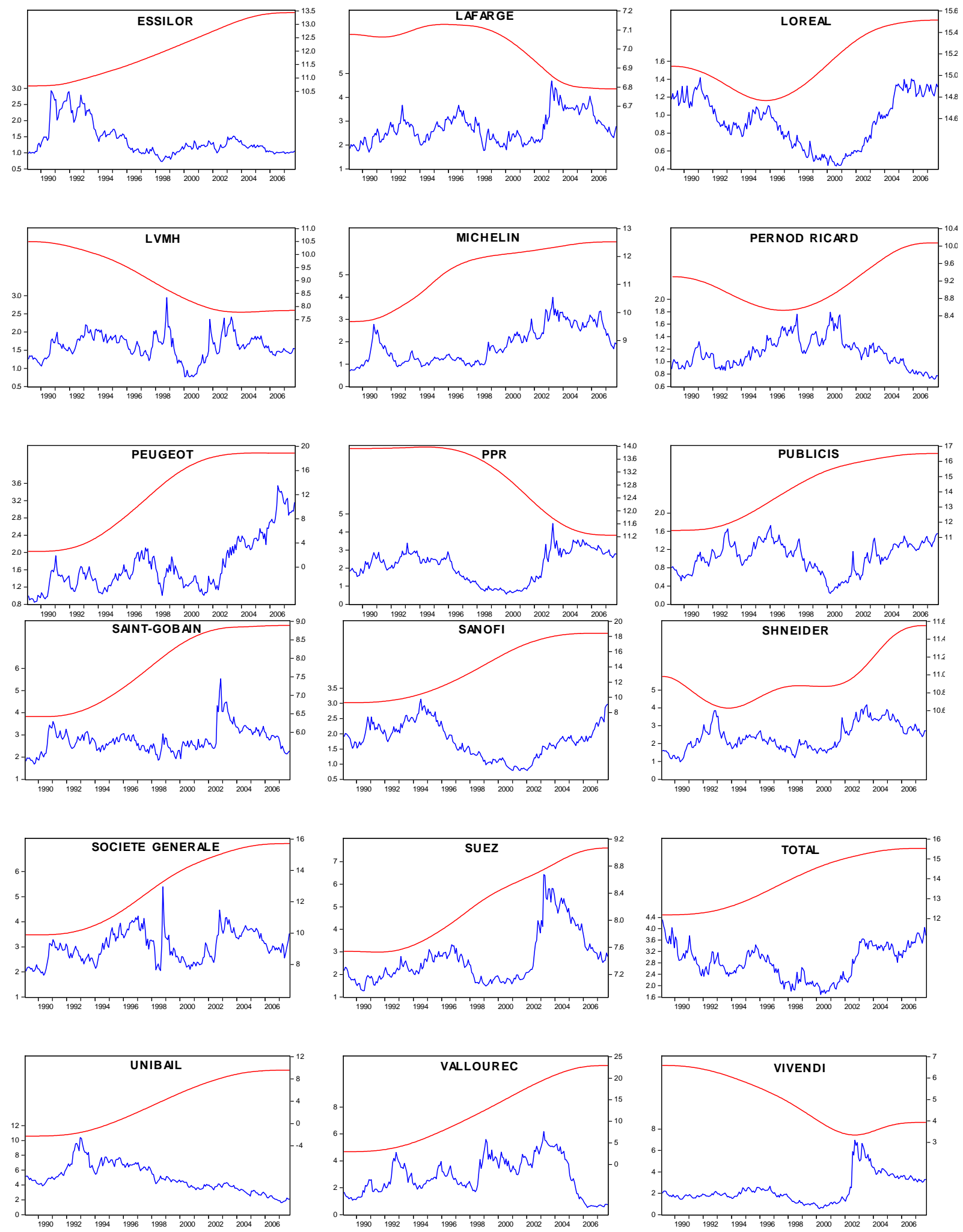

Notes on Figure 1 - All series are in \% per year. For each firm, the dividend yield $\bar{D}_{i t} / P_{i t}$ is the volatile series (left-hand scale) while the long-term dividend growth rate $\bar{g}_{i t}$ is the smoothed series (right-hand scale).

Concerning the choice of common equity factors, we conducted an investigation of the variables (mentioned above) that were repeatedly identified in the literature on the APT. As a result, the seven variables ${ }_{j} X_{t}(j=1 \ldots, 7)$ listed hereafter were found significant for 
most of the 27 equities considered. Four of them are domestic variables and three are international variables :

\section{Domestic factors:}

- ${ }_{1} X_{t}$ is the French stock market factor: ${ }_{1} X_{t}=\frac{D_{m t}}{P_{m t}}+\tilde{g}_{m t}-r_{o t}$ (\% per annum); this factor represents the expected excess long-term return on the French stock market, with:

$P_{m t}$ as the CAC40 stock index, $D_{m t}$ refers to dividends associated with $P_{m t}$, $\bar{g}_{m t}=\log \bar{D}_{m t} / \bar{D}_{m t-1}$, with $\log \bar{D}_{m t}$ the Hodrick-Prescott filter trend of $\log D_{m t}, \quad \tilde{g}_{m t}-\bar{g}_{m t}=\lambda_{m}\left(g_{o m}-\bar{g}_{m t}\right)$, where $g_{o m}$ is the 'normal' value of the rate of growth in $D_{m t}$, and $r_{o t}$ denotes the HP yield trend for French government bonds $r f_{t}$.

- ${ }_{2} X_{t}$ is the French Economic Sentiment Index: ${ }_{2} X_{t}=E S I_{t}-100$ ( \%), where the Economic Sentiment Index $(E S I$, mean=100) is an average of confidence indices built by using surveys concerning activity in four economic sectors (industry, services, construction and retail trade) and consumer satisfaction. Each of these five specific confidence indices is the s.a. balance between positive and negative opinions of perceived and future changes in the field concerned. The surveys are designed in accordance with standardized surveys in the EU area. Overall, the ESI can be viewed as including the influence of production or consumption growth rate and inflation rate, which often appeared as significant factors in the APT studies. During our sample period, we indeed found that over $50 \%$ of the ESI variance can be explained by a linear combination of inflation rate (negatively) and of the rate of growth in industrial production (positively).

- ${ }_{3} X_{t}$ is the interest rates term spread: ${ }_{3} X_{t}=r_{t}-r b_{t}$ (\% per annum) with $r_{t}$ the yield on French corporate bonds (TMO) and $r b_{t}$ the French Interbank rates (Euro Franc and, after the introduction of the Euro, the 12-month Euribor).

- ${ }_{4} X_{t}$ is the default spread of interest rates: ${ }_{4} X_{t}=r_{t}-r f_{t}$ (\% per annum), where $r_{t}$ is the yield on French corporate bonds (TMO) and $r f_{t}$ the yield on French government bonds.

\section{International factors: ${ }^{20}$}

- ${ }_{5} X_{t}$ is the world stock market factor: ${ }_{5} X_{t}=\frac{D_{w t}}{P_{w t}}+\tilde{g}_{w t}-r_{w o t}$ (\% per annum), which represents the expected excess long-term return in the global stock market, with $P_{w t}$ defining the MSCI world stock price index (local currency),

\footnotetext{
${ }^{20}$ The world inflation rate was also considered, but this variable appeared significant for only 4 of the 27 equities considered, so it was excluded from the set of potential factors.
} 
$D_{w t}$ referring to dividends associated with $P_{w t}, \bar{g}_{w t}=\log \bar{D}_{w t} / \bar{D}_{w t-1}$ where $\log \bar{D}_{w t}$ is the Hodrick-Prescott filter trend of $\log D_{w t}$. $\tilde{g}_{w t}-\bar{g}_{w t}=\lambda_{w}\left(g_{w o}-\bar{g}_{w t}\right)$, where $g_{w o}$ is the 'normal' value of the rate of growth in $D_{w t}, r_{w o t}$ is the US federal bond yield.

- ${ }_{6} X_{t}$ is the WTI oil price expressed in euros: ${ }^{21}{ }_{6} X_{t}=100\left(\log W T I_{t} \cdot s_{t}-\right.$ mean $)$ (\%), where WTI is the oil price per barrel expressed in USD, and $S_{t}$ is the spot exchange rate (euros per dollar). We alternatively considered $W T I_{t}$ expressed in real terms (i.e. deflated by the world commodity price index) which gave us similar results.

- ${ }_{7} X_{t}$ Euro/USD (euros per dollar) Exchange rate: ${ }_{7} X_{t}=100\left(\log s_{t}-\right.$ mean) (\%). It may be noted that the log-level of this exchange rate gave much better results than its rate of change. Moreover, the variance of the latter was also considered to capture the risk of change, and this was also the case for the covariance between the equity returns and the rate of change in exchange rate. We found that variance appeared significant at the 5\% level for only 2 of the 27 equities, while covariance was significant for only 3 equities. As a result, these variances and covariances were excluded from the set of common factors.

It may be noted that, since any ${ }_{j} X_{t}$ is related with market rates or yields $\left({ }_{1} X_{t},{ }_{3} X_{t}\right.$, $\left.{ }_{4} X_{t},{ }_{5} X_{t}\right)$, with market price $\left({ }_{6} X_{t},{ }_{7} X_{t}\right)$, or with a synthetic opinion index on the future state of the economy $\left({ }_{2} X_{t}\right)$, all of them might be viewed as carrying expectations that theoretically underlie the $k$ components ${ }_{j} \varphi_{t}$ of the long-term risk premia. ${ }^{22} \mathrm{Next}$, for statistical purposes and to ensure that the variables ${ }_{j} X_{t}$ are close to statistical independency, the French market factor ${ }_{1} X_{t}$ was modified into ${ }_{1} X_{t}^{*}$, representing the part of this variable uncorrelated with other domestic factors, namely, the residual of the regression of ${ }_{1} X_{t}$ on the three other domestic factors. Moreover, the world market factor ${ }_{5} X_{t}$ was changed into ${ }_{5} X_{t}^{*}$ representing the part of this variable uncorrelated with all other factors, namely, the residual of the regression of ${ }_{5} X_{t}$ on the six other factors. Figure 2 reports the time series of the seven common factors ${ }_{j} X_{t}$ as well the risk-free rate $r_{o t}$ estimated by the HP trend of the yield on French government bonds $r f_{t}$ (although $r_{o t}$ is not an APT-common factor, it is nevertheless a DDM-common factor). It can be seen that the ${ }_{j} X_{t}$ are highly fluctuating and pretty much independent of each other, as confirmed by the weak correlations shown in Table 1.

\footnotetext{
${ }^{21}$ We alternatively expressed this variable in real terms (i.e. deflated by the world commodity price index) but the results remained quite similar.

${ }^{22}$ Stock price indices, exchange rate and oil price are dated at the end of the month (as are equity prices), while interest rates and the Economic Sentiment Index are monthly averages.
} 
Figure 2 - Dynamics of the common equity factors
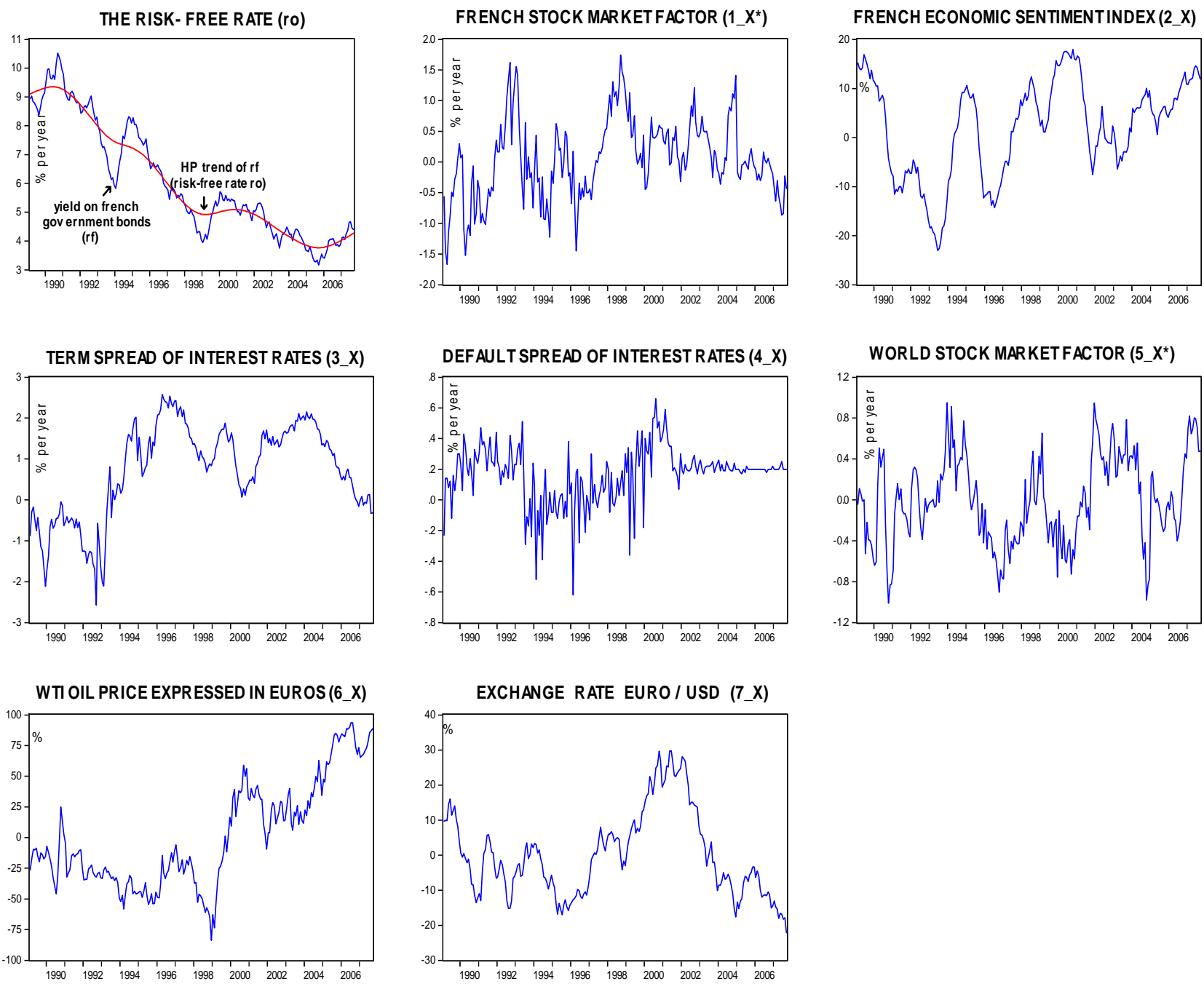

Notes for Figure $2-{ }_{1} X_{t}^{*},{ }_{2} X_{t},{ }_{3} X_{t},{ }_{4} X_{t}$ and ${ }_{5} X_{t}^{*}$ are in \% per annum; ${ }_{2} X_{t},{ }_{6} X_{t}$ and ${ }_{7} X_{t}$ are in \% compared to the average value.

Table 1 - Correlation matrix for the seven common factors

\begin{tabular}{cccccccc} 
& ${ }_{1} X_{t}^{*}$ & ${ }_{2} X_{t}$ & ${ }_{3} X_{t}$ & ${ }_{4} X_{t}$ & ${ }_{5} X_{t}^{*}$ & ${ }_{6} X_{t}$ & ${ }_{7} X_{t}$ \\
\hline \hline & & & & & & & \\
${ }_{1} X_{t}^{*}$ & 1.00 & 0.01 & -0.01 & -0.00 & 0.00 & 0.27 & -0.03 \\
${ }_{2} X_{t}$ & & 1.00 & 0.04 & 0.19 & -0.01 & 0.33 & 0.24 \\
${ }_{3} X_{t}$ & & & 1.00 & -0.24 & 0.01 & 0.05 & 0.04 \\
${ }_{4} X_{t}$ & & & & 1.00 & -0.00 & 0.34 & 0.23 \\
${ }_{5} X_{t}^{*}$ & & & & & 1.00 & -0.02 & 0.02 \\
${ }_{6} X_{t}$ & & & & & & 1.00 & 0.01 \\
${ }_{7} X_{t}$ & & & & & & & \\
\end{tabular}


Notes on Table $1-{ }_{1} X_{t}^{*}$ is the French stock market factor; ${ }_{2} X_{t}$ is the Economic Sentiment Index; ${ }_{3} X_{t}$ is the Term spread of interest rates; ${ }_{4} X_{t}$ is the Default spread of interest rates; ${ }_{5} X_{t}^{*}$ is the World stock market factor; ${ }_{6} X_{t}$ is the WTI oil price expressed in euros; ${ }_{7} X_{t}$ is the Exchange rate (Euro/USD).

\subsection{Fundamental value estimation}

The endogenous variable $\frac{\overline{D_{i t}}}{P_{i t}}-r_{o t}$ of equation (6) was found to be non- stationary for all equities on the basis of ADF unit root tests, which result from the dynamics of the riskfree discount rate $r_{o t}$ and of the $\frac{\bar{D}_{i t}}{P_{i t}}$ ratios (Figure 1). Accordingly, at least one exogenous variable must be non-stationary in (6). The application of ADF tests showed that all of the $\bar{g}_{i t}$ $(i=1 \ldots, 27)$ exhibit a unit root; the common factors ${ }_{6} X_{t}$ (oil price) and ${ }_{7} X_{t}$ (foreign exchange rate) are also found to be non-stationary, while the factors ${ }_{1} X_{t},{ }_{2} X_{t},{ }_{4} X_{t}$ and ${ }_{5} X_{t}$ are stationary at the $5 \%$ level (at $10 \%$ for ${ }_{3} X_{t}$ ). ${ }^{23}$

Since risk premia for all companies depend on the same set of common factors, this can induce contemporaneous correlations between the residuals of equation (6) for the 27 firms and be a source of bias in estimating this equation with the OLS method. ${ }^{24}$ Accordingly, equation (6) was estimated simultaneously for the 27 equities using the Seemingly Unrelated Regression (SUR) method, which is robust to both the contemporaneous correlations and the heteroscedasticity of residuals. ${ }^{25}$ Table 2 shows that $91 \%$ of the estimates are significant at the $5 \%$ level. Furthermore, although the signs of coefficients $\hat{\gamma}_{i j}$ vary across firms, we found that the proportion of estimates ${ }_{j} \hat{\gamma}_{i}$ having the same sign among the firms for each ${ }_{j} X_{t}$ are generally quite high: they are positive for $96 \%$ of firms with the French market factor, for $86 \%$ of firms with the world market factor, for $93 \%$ of firms with the term spread, for $48 \%$ of

\footnotetext{
${ }^{23}$ We do not report the results of the ADF tests to save space.

${ }^{24}$ As indicated by equation (6), residuals capture both specific factors of risk and the error term of the model. It follows that if the DDM was specified with certainty, if the common factors of risk premia were perfectly identified and if share prices adjusted instantaneously to their fundamental values, then correlations between the residuals for all 27 firms would be insignificant even though the same set of common factors intervenes for all equities. Indeed, in this polar case, residuals represent factors of risk that are firm specific.

${ }^{25}$ For comparison, we estimated equation (6) for the 27 firms using OLS and found that the matrix of estimates was very different to that obtained with the SUR method. Instead of the latter, we could of course use another method, especially the GMM method (Generalized Method of Moments). We preferred the SUR method since it avoids the arbitrary choice of instruments to which the results are often rather sensitive. A panel approach (possible with our cylindered data) was not really appropriate in so far as, besides the intercepts, all slopes related to the 27 firms are a priori firm-dependent, which was checked a posteriori.
} 
firms with the default spread, and for $81 \%$ of firms with oil price. ${ }^{26}$ The signs are negative for $86 \%$ of firms with the euro/USD exchange rate and for 52\% with the French Economic Sentiment Index. Despite the fact that these results suggest some common behaviour across firms, it seems clear that none of the slopes or intercepts can be assumed to have the same value for all firms, so it appears unnecessary to consider statistical tests here to answer this question. Overall, the set of ${ }_{j} X_{t}$ taken into consideration can reasonably be viewed as representing common factors to which equities react with specific sensitivity. Concerning long-term expected dividend growth rate, the estimated values of $\hat{\lambda}_{i}=\hat{\theta}_{l}+1$ are positive for $23 / 27$ of the firms (85\%), indicating that the expected rate follows a mean-reversion process toward its normal value. For 3 firms (Air France, Axa, Pernod Ricard), the values of $\hat{\lambda}_{i}$ are negative but near zero, meaning that the expected rates are close to the long-term perceived growth rates, while we found a significant negative value for LVMH, meaning that the difference between the expected rate and its normal value is expected to increase.

To check for the adequacy of our estimation, we performed some diagnostic tests. The $A D F$ test shows that the residuals of equation (6) are stationary at the $1 \%$ level for $6 / 27$ firms, at 5\% level for 10/27 firms, and at 10\% level for 25/27 firms (Danone and Sanofi are not stationary at this last level). ${ }^{27}$ Finally, the $D W$ statistic indicates significant autocorrelation of residuals for all firms; this property implies that deviations between prices and fundamental values are also serially correlated, and this property suggests the hypothesis - analysed hereafter - of a mean-reversion mechanism of the market price toward the fundamental value.

Table 2 - Risk premia estimates

\begin{tabular}{|c|c|c|c|c|c|c|c|c|c|c|c|c|}
\hline $\begin{array}{l}\text { Estimates } \\
\text { Firms } i\end{array}$ & $\hat{\theta}_{i}$ & ${ }_{1} \hat{\gamma}_{i}$ & $2 \hat{\gamma}_{i}$ & $3 \hat{\gamma}_{i}$ & ${ }_{4} \hat{\gamma}_{i}$ & $5 \hat{\gamma}_{i}$ & $6 \hat{\gamma}_{i}$ & $7 \hat{\gamma}_{i}$ & $c_{i}$ & $\bar{R}^{2}$ & $D W$ & $A D F$ \\
\hline Accor & $\begin{array}{l}-0.90 \\
-7.8\end{array}$ & $\begin{array}{l}1.12 \\
17.5\end{array}$ & _ & $\begin{array}{l}1.06 \\
25.2\end{array}$ & $\begin{array}{l}0.23 \\
2.2\end{array}$ & $\begin{array}{l}0.71 \\
8.8\end{array}$ & $\begin{array}{l}0.02 \\
10.0\end{array}$ & $\begin{array}{l}-0.03 \\
-13.9\end{array}$ & $\begin{array}{l}2.87 \\
3.0\end{array}$ & 0.97 & 0.37 & $\begin{array}{l}-4.81 \\
(*)\end{array}$ \\
\hline Air France & $\begin{array}{l}-1.13 \\
-17.8 \\
\end{array}$ & $\begin{array}{l}-1.55 \\
-5.5 \\
\end{array}$ & - & - & $\begin{array}{l}-2.42 \\
-.3 .3 \\
\end{array}$ & $\begin{array}{l}-3.4 \\
-9.2\end{array}$ & $\begin{array}{l}-0.08 \\
-15.2\end{array}$ & $\begin{array}{l}-0.10 \\
-7.3\end{array}$ & $\begin{array}{l}-18.1 \\
-18.3\end{array}$ & 0.58 & 0.35 & $\begin{array}{l}-4.63 \\
(* *)\end{array}$ \\
\hline $\begin{array}{l}\text { Air } \\
\text { Liquide }\end{array}$ & $\begin{array}{l}1.66 \\
37.8\end{array}$ & $\begin{array}{l}0.44 \\
12.2\end{array}$ & $\begin{array}{l}0.01 \\
5.2\end{array}$ & $\begin{array}{l}0.37 \\
19.0\end{array}$ & - & $\begin{array}{l}0.14 \\
4.1\end{array}$ & $\begin{array}{l}0.003 \\
4.7\end{array}$ & $\begin{array}{l}-0.02 \\
-11.4\end{array}$ & $\begin{array}{l}-20.2 \\
-49.5\end{array}$ & 0.98 & 0.23 & $\begin{array}{l}-3.81 \\
(* * *)\end{array}$ \\
\hline Alcatel & -0.10 & 0.54 & 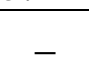 & 0.55 & -0.64 & 0.40 & 0.01 & -0.01 & 5.63 & 0.84 & 0.52 & -4.91 \\
\hline
\end{tabular}

\footnotetext{
${ }^{26}$ Surprisingly, oil price appeared insignificant for Total. This suggests that, on average, the negative effect on risk premium arising from an expected increase in the supply side of the oil market is compensated for by the positive effect resulting from an expected decrease in oil demand. Otherwise, the fact that the WTI market relates to crude oil price while Total is concerned with production and refining for both oil and gas, adds uncertainty with regard to the resulting effect.

${ }^{27}$ The tenuous results concerning the $A D F$ tests are mainly due to the existence of a few extreme values in the residuals of equation (6). We did not eliminate these points by using dummies since the deviations between equity prices and fundamental values analyzed hereafter also contain these extreme values that may intervene in the adjustment process of share prices towards fundamentals.
} 


\begin{tabular}{|c|c|c|c|c|c|c|c|c|c|c|c|c|}
\hline & -4.4 & 5.8 & & 8.9 & -3.8 & 3.2 & 2.4 & -4.3 & -28.6 & & & $(*)$ \\
\hline Axa & $\begin{array}{l}-1.07 \\
-5.1\end{array}$ & $\begin{array}{l}1.70 \\
45.2\end{array}$ & $\begin{array}{l}0.01 \\
3.6\end{array}$ & $\begin{array}{l}1.29 \\
63.5\end{array}$ & $\begin{array}{l}0.56 \\
6.0\end{array}$ & $\begin{array}{l}1.67 \\
30.5\end{array}$ & $\begin{array}{l}0.04 \\
52.8\end{array}$ & $\begin{array}{l}-0.05 \\
-26.0\end{array}$ & $\begin{array}{l}9.21 \\
3.4\end{array}$ & 0.98 & 0.64 & $\begin{array}{l}-5.01 \\
(*)\end{array}$ \\
\hline Bouygues & $\begin{array}{l}0.10 \\
3.7\end{array}$ & $\begin{array}{l}0.92 \\
13.4\end{array}$ & - & $\begin{array}{l}0.97 \\
25.8\end{array}$ & - & $\begin{array}{l}0.35 \\
4.4\end{array}$ & $\begin{array}{l}0.01 \\
6.2\end{array}$ & $\begin{array}{l}-0.04 \\
-13.9\end{array}$ & $\begin{array}{l}-5.5 \\
-24.7\end{array}$ & 0.90 & 0.34 & $\begin{array}{l}-3.88 \\
(* * *)\end{array}$ \\
\hline Capgémini & - & $\begin{array}{l}1.46 \\
34.0\end{array}$ & - & $\begin{array}{l}1.13 \\
48.9\end{array}$ & - & $\begin{array}{l}1.37 \\
23.8\end{array}$ & $\begin{array}{l}0.03 \\
54.3\end{array}$ & $\begin{array}{l}-0.04 \\
-19.9\end{array}$ & $\begin{array}{l}-5.5 \\
-174.3\end{array}$ & 0.97 & 0.47 & $\begin{array}{l}-4.41 \\
(*)\end{array}$ \\
\hline Carre & $\begin{array}{l}3.34 \\
17.5\end{array}$ & $\begin{array}{l}0.76 \\
15.2\end{array}$ & $\begin{array}{l}0.01 \\
4.5\end{array}$ & $\begin{array}{l}0.32 \\
9.2\end{array}$ & - & $\begin{array}{l}1.00 \\
15.9\end{array}$ & $\begin{array}{l}0.03 \\
35.3\end{array}$ & $\begin{array}{l}-0.03 \\
-12.4\end{array}$ & $\begin{array}{l}-51.3 \\
-19.4\end{array}$ & 0.96 & 0.19 & $\begin{array}{l}-3.82 \\
(* * *)\end{array}$ \\
\hline Danone & $\begin{array}{c}0.95 \\
15.6 \\
\end{array}$ & $\begin{array}{l}0.86 \\
18.3 \\
\end{array}$ & $\begin{array}{l}0.02 \\
9.7 \\
\end{array}$ & $\begin{array}{l}0.97 \\
41.2 \\
\end{array}$ & $\begin{array}{l}0.17 \\
2.1 \\
\end{array}$ & $\begin{array}{l}0.39 \\
8.3 \\
\end{array}$ & $\begin{array}{l}0.01 \\
10.3\end{array}$ & $\begin{array}{l}-0.02 \\
-6.9\end{array}$ & $\begin{array}{l}-13.8 \\
-25.3 \\
\end{array}$ & 0.95 & 0.30 & -3.42 \\
\hline Essilor & $\begin{array}{l}0.78 \\
13.1\end{array}$ & $\begin{array}{l}0.78 \\
17.6\end{array}$ & $\begin{array}{l}-0.01 \\
-5.9\end{array}$ & $\begin{array}{l}0.48 \\
16.7\end{array}$ & $\begin{array}{l}1.00 \\
10.9\end{array}$ & - & $\begin{array}{l}0.01 \\
8.8\end{array}$ & $\begin{array}{l}-0.01 \\
-5.7\end{array}$ & $\begin{array}{l}-14.6 \\
-21.0\end{array}$ & 0.96 & 0.23 & $\begin{array}{l}-3.85 \\
(* * *)\end{array}$ \\
\hline Lafa & $\begin{array}{l}0.96 \\
2.7 \\
\end{array}$ & $\begin{array}{l}1.53 \\
28.5\end{array}$ & - & $\begin{array}{l}1.20 \\
43.2 \\
\end{array}$ & $\begin{array}{l}0.89 \\
6.9 \\
\end{array}$ & $\begin{array}{l}1.08 \\
15.1\end{array}$ & $\begin{array}{l}0.03 \\
27.3 \\
\end{array}$ & $\begin{array}{l}-0.04 \\
-13.0 \\
\end{array}$ & $\begin{array}{l}-11.1 \\
-4.4\end{array}$ & 0.95 & 0.35 & $\begin{array}{l}-4.70 \\
(* *)\end{array}$ \\
\hline L'Ore & $\begin{array}{l}-0.21 \\
-2.0\end{array}$ & $\begin{array}{l}1.10 \\
24.8\end{array}$ & $\begin{array}{l}0.03 \\
13.4\end{array}$ & $\begin{array}{l}0.88 \\
39.0\end{array}$ & $\begin{array}{l}0.24 \\
2.7\end{array}$ & $\begin{array}{l}1.02 \\
18.0\end{array}$ & $\begin{array}{l}0.03 \\
31.6\end{array}$ & $\begin{array}{l}-0.03 \\
-10.6\end{array}$ & $\begin{array}{l}-2.70 \\
-1.94\end{array}$ & 0.94 & 0.21 & $\begin{array}{l}3.84 \\
(* * *)\end{array}$ \\
\hline LVN & $\begin{array}{c}-1.48 \\
-49.1\end{array}$ & $\begin{array}{l}0.53 \\
13.2\end{array}$ & $\begin{array}{l}-0.01 \\
-2.2\end{array}$ & $\begin{array}{l}0.29 \\
12.4\end{array}$ & $\begin{array}{l}-0.33 \\
-4.1\end{array}$ & $\begin{array}{l}0.41 \\
9.7\end{array}$ & - & $\begin{array}{l}-0.03 \\
-13.5\end{array}$ & $\begin{array}{c}8.7 \\
29.9\end{array}$ & 0.97 & 39 & $\begin{array}{l}-3.53 \\
(* * *)\end{array}$ \\
\hline Micl & $\begin{array}{l}0.86 \\
16.7 \\
\end{array}$ & $\begin{array}{l}0.98 \\
17.2 \\
\end{array}$ & $\begin{array}{l}-0.01 \\
-2.0 \\
\end{array}$ & $\begin{array}{l}0.70 \\
17.2 \\
\end{array}$ & $\begin{array}{l}1.08 \\
8.9 \\
\end{array}$ & $\begin{array}{l}0.96 \\
13.0\end{array}$ & $\begin{array}{l}0.03 \\
30.5\end{array}$ & $\begin{array}{l}-0.01 \\
-3.6\end{array}$ & $\begin{array}{l}-14.9 \\
-26.2\end{array}$ & 0.97 & 0.29 & $\begin{array}{l}-4.00 \\
(* * *)\end{array}$ \\
\hline $\begin{array}{l}\text { Pernod } \\
\text { Ricard }\end{array}$ & $\begin{array}{l}-1.06 \\
-17.5\end{array}$ & $\begin{array}{l}1.26 \\
26.3\end{array}$ & $\begin{array}{l}0.03 \\
12.0\end{array}$ & $\begin{array}{l}0.99 \\
38.6\end{array}$ & $\begin{array}{l}0.68 \\
5.9\end{array}$ & $\begin{array}{l}1.13 \\
17.1\end{array}$ & $\begin{array}{l}0.03 \\
32.9\end{array}$ & $\begin{array}{l}-0.02 \\
-5.4\end{array}$ & $\begin{array}{c}3.8 \\
6.8\end{array}$ & 0.94 & 0.21 & $\begin{array}{l}-3.82 \\
(* * *)\end{array}$ \\
\hline Peuq & $\begin{array}{l}0.34 \\
59.7\end{array}$ & $\begin{array}{l}0.11 \\
2.5\end{array}$ & $\begin{array}{l}-0.01 \\
-3.4\end{array}$ & - & $\begin{array}{l}-0.56 \\
-6.9\end{array}$ & - & $\begin{array}{l}0.003 \\
3.7\end{array}$ & $\begin{array}{l}-0.05 \\
-20.2\end{array}$ & $\begin{array}{l}-8.3 \\
-117.2\end{array}$ & 97 & 25 & $\begin{array}{l}-3.82 \\
(* * *)\end{array}$ \\
\hline PPR & $\begin{array}{l}-0.58 \\
-11.5\end{array}$ & $\begin{array}{l}0.99 \\
22.0\end{array}$ & $\begin{array}{l}-0.01 \\
-5.5\end{array}$ & $\begin{array}{l}0.76 \\
32.5\end{array}$ & - & $\begin{array}{l}1.06 \\
16.7\end{array}$ & $\begin{array}{l}0.02 \\
18.6\end{array}$ & $\begin{array}{l}-0.05 \\
-21.1\end{array}$ & $\begin{array}{l}3.0 \\
4.5\end{array}$ & 0.97 & 0.53 & $\begin{array}{l}-4.31 \\
(* *)\end{array}$ \\
\hline Publ & $\begin{array}{l}0.91 \\
68.3\end{array}$ & $\begin{array}{l}0.32 \\
9.0\end{array}$ & $\begin{array}{l}-0.01 \\
-6.0\end{array}$ & $\begin{array}{l}0.18 \\
9.7\end{array}$ & $\begin{array}{l}-0.38 \\
-6.1\end{array}$ & $\begin{array}{l}0.13 \\
3.8\end{array}$ & - & $\begin{array}{l}-0.03 \\
-17.3\end{array}$ & $\begin{array}{l}-18.0 \\
-100.1\end{array}$ & 0.97 & 0.35 & $\begin{array}{l}-3.57 \\
(* * *)\end{array}$ \\
\hline $\begin{array}{l}\text { Saint } \\
\text { Gobain }\end{array}$ & $\begin{array}{l}1.19 \\
15.4\end{array}$ & $\begin{array}{l}0.82 \\
14.4\end{array}$ & $\begin{array}{l}-0.02 \\
-8.8\end{array}$ & $\begin{array}{l}0.61 \\
15.4\end{array}$ & $\begin{array}{l}0.64 \\
5.8\end{array}$ & $\begin{array}{l}0.54 \\
8.1\end{array}$ & $\begin{array}{l}0.01 \\
9.3\end{array}$ & $\begin{array}{l}-0.02 \\
-11.5\end{array}$ & $\begin{array}{l}-13.1 \\
-23.1\end{array}$ & 0.97 & .60 & $\begin{array}{l}-6.17 \\
\left(^{*}\right)\end{array}$ \\
\hline Sanofi & $\begin{array}{c}0.15 \\
7.0\end{array}$ & $\begin{array}{l}0.71 \\
11.7\end{array}$ & $\begin{array}{l}0.02 \\
6.8\end{array}$ & $\begin{array}{l}0.62 \\
17.4\end{array}$ & $\begin{array}{l}-0.23 \\
-2.1\end{array}$ & $\begin{array}{l}0.81 \\
11.9\end{array}$ & $\begin{array}{l}0.01 \\
10.4\end{array}$ & $\begin{array}{l}-0.04 \\
-16.3\end{array}$ & $\begin{array}{l}-6.82 \\
-25.4\end{array}$ & 0.93 & 0.18 & -3.04 \\
\hline Schr & $\begin{array}{l}1.42 \\
10.6\end{array}$ & $\begin{array}{l}1.70 \\
40.8\end{array}$ & $\begin{array}{l}-0.02 \\
-8.3\end{array}$ & $\begin{array}{l}1.12 \\
48.1\end{array}$ & $\begin{array}{l}0.99 \\
7.4\end{array}$ & $\begin{array}{l}1.46 \\
24.0\end{array}$ & $\begin{array}{l}0.03 \\
30.2\end{array}$ & $\begin{array}{l}-0.02 \\
-9.7\end{array}$ & $\begin{array}{l}-20.3 \\
-13.8\end{array}$ & 0.97 & 0.48 & $\begin{array}{l}-5.63 \\
(*)\end{array}$ \\
\hline $\begin{array}{l}\text { Société } \\
\text { Générale }\end{array}$ & $\begin{array}{l}0.82 \\
21.6\end{array}$ & $\begin{array}{l}0.45 \\
7.3\end{array}$ & $\begin{array}{l}-0.01 \\
-5.2\end{array}$ & $\begin{array}{l}0.54 \\
13.6\end{array}$ & - & $\begin{array}{l}-0.12 \\
-1.8\end{array}$ & $\begin{array}{l}-0.03 \\
-15.0\end{array}$ & $\begin{array}{l}-0.004 \\
-2.5\end{array}$ & $\begin{array}{l}-13.9 \\
-30.4\end{array}$ & 0.97 & 0.68 & $\begin{array}{l}-6.71 \\
(*)\end{array}$ \\
\hline Suez & $\begin{array}{c}1.23 \\
7.2\end{array}$ & $\begin{array}{l}1.29 \\
16.2\end{array}$ & $\begin{array}{l}-0.01 \\
-2.5\end{array}$ & $\begin{array}{l}1.22 \\
23.8\end{array}$ & $\begin{array}{l}0.49 \\
2.8\end{array}$ & $\begin{array}{l}1.08 \\
9.9\end{array}$ & $\begin{array}{l}0.03 \\
14.1\end{array}$ & $\begin{array}{l}-0.04 \\
-12.4\end{array}$ & $\begin{array}{l}-14.5 \\
-10.6\end{array}$ & 0.95 & 0.29 & $\begin{array}{l}-4.47 \\
(* *)\end{array}$ \\
\hline Total & $\begin{array}{l}1.46 \\
57.3\end{array}$ & $\begin{array}{l}0.07 \\
1.9\end{array}$ & $\begin{array}{l}0.004 \\
2.0\end{array}$ & $\begin{array}{l}0.07 \\
2.7\end{array}$ & $\begin{array}{l}-0.69 \\
-6.5\end{array}$ & $\begin{array}{l}0.12 \\
2.4\end{array}$ & - & $\begin{array}{l}-0.03 \\
-18.3\end{array}$ & $\begin{array}{l}-23.4 \\
-70.0\end{array}$ & 0.97 & 0.52 & $\begin{array}{l}-3.55 \\
(* * * \\
)\end{array}$ \\
\hline Unib & $\begin{array}{l}-0.32 \\
-7.9\end{array}$ & $\begin{array}{l}2.05 \\
14.7\end{array}$ & $\begin{array}{l}-0.02 \\
-3.5\end{array}$ & $\begin{array}{l}1.40 \\
15.4\end{array}$ & $\begin{array}{l}1.19 \\
4.1\end{array}$ & $\begin{array}{l}1.12 \\
6.5\end{array}$ & $\begin{array}{l}0.02 \\
6.0\end{array}$ & $\begin{array}{l}-0.03 \\
-5.3\end{array}$ & $\begin{array}{l}-1.26 \\
-10.8\end{array}$ & 0.64 & 0.21 & $\begin{array}{l}-3.89 \\
(* * *)\end{array}$ \\
\hline Vallo & $\begin{array}{l}0.15 \\
15.7\end{array}$ & $\begin{array}{l}1.65 \\
19.5\end{array}$ & $\begin{array}{l}-0.03 \\
-7.0\end{array}$ & $\begin{array}{l}1.24 \\
22.8\end{array}$ & $\begin{array}{l}2.77 \\
10.0\end{array}$ & $\begin{array}{l}0.63 \\
5.2\end{array}$ & - & $\begin{array}{l}0.02 \\
3.6\end{array}$ & $\begin{array}{l}-6.4 \\
-61.1\end{array}$ & 0.92 & 0.37 & $\begin{array}{l}-3.68 \\
(* * *)\end{array}$ \\
\hline Vivendi & $\begin{array}{c}-0.24 \\
-2.4\end{array}$ & $\begin{array}{l}1.49 \\
14.4\end{array}$ & $\begin{array}{l}-0.01 \\
-2.7\end{array}$ & $\begin{array}{l}1.17 \\
16.7\end{array}$ & - & $\begin{array}{l}1.84 \\
14.3\end{array}$ & $\begin{array}{l}0.04 \\
18.4\end{array}$ & $\begin{array}{l}-0.05 \\
-11.6\end{array}$ & $\begin{array}{l}-3.4 \\
-6.2\end{array}$ & 0.93 & 0.30 & $\begin{array}{l}-3.84 \\
(* * *)\end{array}$ \\
\hline signif & $26 / 27$ & $27 / 27$ & $21 / 2$ & $25 / 2$ & $20 / 2$ & $25 / 2$ & $23 / 2$ & $27 / 27$ & $26 / 2$ & & & \\
\hline
\end{tabular}




\begin{tabular}{|l|c|c|l|l|l|l|l|l|l|l|l|l|}
\hline & $96 \%$ & $100 \%$ & 7 & 7 & 7 & 7 & 7 & $100 \%$ & 7 & & & \\
\hline & & & $78 \%$ & $93 \%$ & $74 \%$ & $93 \%$ & $85 \%$ & & $96 \%$ & & & \\
\hline & for $\hat{\lambda}_{i}=\hat{\theta}_{i}+1$ & & & & & & & & & & & \\
$n b(-)$ & $85 \%$ & $96 \%$ & $26 \%$ & $93 \%$ & $48 \%$ & $86 \%$ & $81 \%$ & $4 \%$ & $19 \%$ & & & \\
$n b(0)$ & $15 \%$ & $4 \%$ & $52 \%$ & $0 \%$ & $26 \%$ & $7 \%$ & $4 \%$ & $86 \%$ & $77 \%$ & & & \\
\hline
\end{tabular}

Notes on Table 2 - The table gives the estimates of equation (6): $\frac{D_{i t}}{P_{i t}}-r_{0 t}=\theta_{i} \bar{g}_{i t}+\sum_{j=1}^{k}{ }_{j} \gamma_{i j} X_{t}+c_{i}+\varepsilon_{i t}$ over the period 1989.02-2007.09 (Nobs $=224$ ). The $t$ statistics of estimates are in italics. $\bar{g}_{i t}=\log \bar{D}_{i t} / \bar{D}_{i t-1}$ with $\log \bar{D}_{i t}$ : trend HP); ${ }_{1} X_{t}^{*}$ is the French stock market factor; ${ }_{2} X_{t}$ is the French Economic Sentiment Index; ${ }_{3} X_{t}$ is the Term spread of interest rates; ${ }_{4} X_{t}$ is the Default spread of interest rates; ${ }_{5} X_{t}^{*}$ is the World stock market factor; ${ }_{6} X_{t}$ is the WTI oil price expressed in euros; ${ }_{7} X_{t}$ is the Exchange rate Euro/USD. "_ ” indicates that the variable was found to be insignificant and then ultimately dropped from the equation. $D W$ stands for the Durbin-Watson statistic. $A D F$ is the Augmented Dickey-Fuller $t$-statistic for residuals where $(*),(* *)$ and $(* * *)$ indicate stationarity at the $1 \%, 5 \%$ and $10 \%$ level respectively. We referred to the Mackinnon critical values for $t$ - statistic (see Engle and Granger, 1991, Table 1, p.275) with 224 observations and $k$ the number of non-stationary variables ( $k=3$ or $k=4$ according to the companies), which gives us:

$\begin{array}{lllc} & 1 \% \text { level } & 5 \% \text { level } & 10 \% \text { level } \\ k=3 & -4.35 & -3.78 & -3.48 \\ k=4 & -4.73 & -4.14 & -4.14\end{array}$

Signif : for a given factor ${ }_{j} X_{t}$, indicates the proportion of significant coefficients (at the $5 \%$ level) among the 27 (note that the total percentage of significant coefficients is $220 /(27 \times 9)=91 \%) . n b$ stands for the $\%$ of positive $(+$ ), negative (-) and null (0) coefficients among the 27 at the $5 \%$ level for a given firm (NB: the first column indicates the

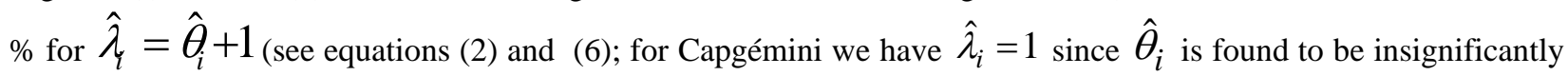
different from zero).

Next, the theoretical difference $\left(\varphi_{i t}-\tilde{g}_{i t}\right)$ in equation (8) is replaced by its estimated value $\left(\varphi_{i t}-\tilde{g}_{i t}\right)^{*}$ given by equation (7), so that in principle we get the estimated fundamental value $F_{i t}^{*}$. However, in practice, for ten of the 27 equities, a positive constant was added to $\left(\varphi_{i t}-\tilde{g}_{i t}\right)^{*}$ to satisfy the theoretical transversality condition $r_{o t}+\left(\varphi_{i t}-\tilde{g}_{i t}\right)^{*}>0$. This was necessary for four companies whose denominators take negative values for three to six months (of the 224 months in the period). For the 6 others companies concerned, although always positive, the $\left(\varphi_{i t}-\tilde{g}_{i t}\right)^{*}$ values were near zero for one to six months, thus generating abnormal erratic movements of $F_{i t}{ }^{*}$ at these dates. ${ }^{28}$ The values of these constants are (\% per annum): Air France (0.3\%), Bouygues (0.1\%), Capgémini (0.3\%), Carrefour (0.45\%), Danone (0.1\%), L'Oreal (0.7\%), Peugeot (0.1\%), Publicis (0.1\%), Sanofi (0.1\%) and Vivendi $(0.2 \%)$. It should be noted that these values are very low and clearly inside the confidence interval at $5 \%$ level implied by the standard errors of the intercepts $\widehat{C}_{i}$, so this procedure can be viewed as a correction due to uncertainty associated with this latter parameter. In practice, the values

\footnotetext{
${ }^{28}$ Overall, only 47 months are concerned, corresponding to less than $1 \%$ of the $224 \times 27=6048$ total number of observations.
} 
of these constants were chosen to minimize the value of $Q_{i}=\sum_{t=1}^{224}\left(p_{i t}-f_{i t}^{*}\right)^{2}$ where $p_{i t}=\log P_{i t}$ and $f_{i t}^{*}=\log F_{i t}^{*}$ under the condition $F_{i t}^{*}>0 \forall t$.

In Figure 3, we showed that the fundamental values represent trends and a substantial part of equity price fluctuations. Moreover, the magnitude of fluctuations in $p_{i t}$ and $f_{i t}^{*}$ are generally quite comparable, and this contrasts with the results in the literature obtained with stock price indices, where the fundamental values are very smooth compared to prices (Manzan, 2003; Boswijk et al., 2007; Jawadi and Prat, 2012).

Figure 3 - Equity prices and fundamental values
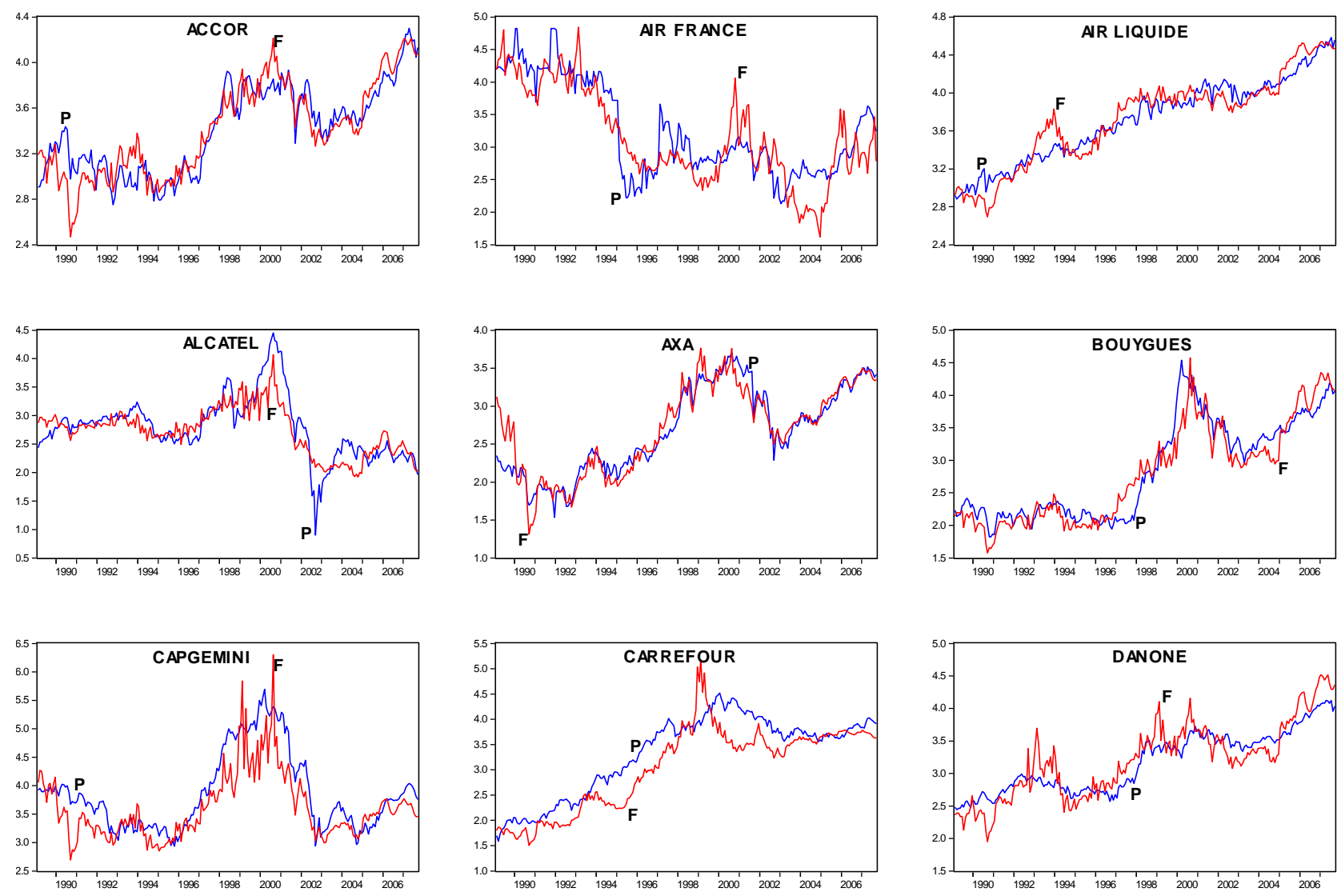

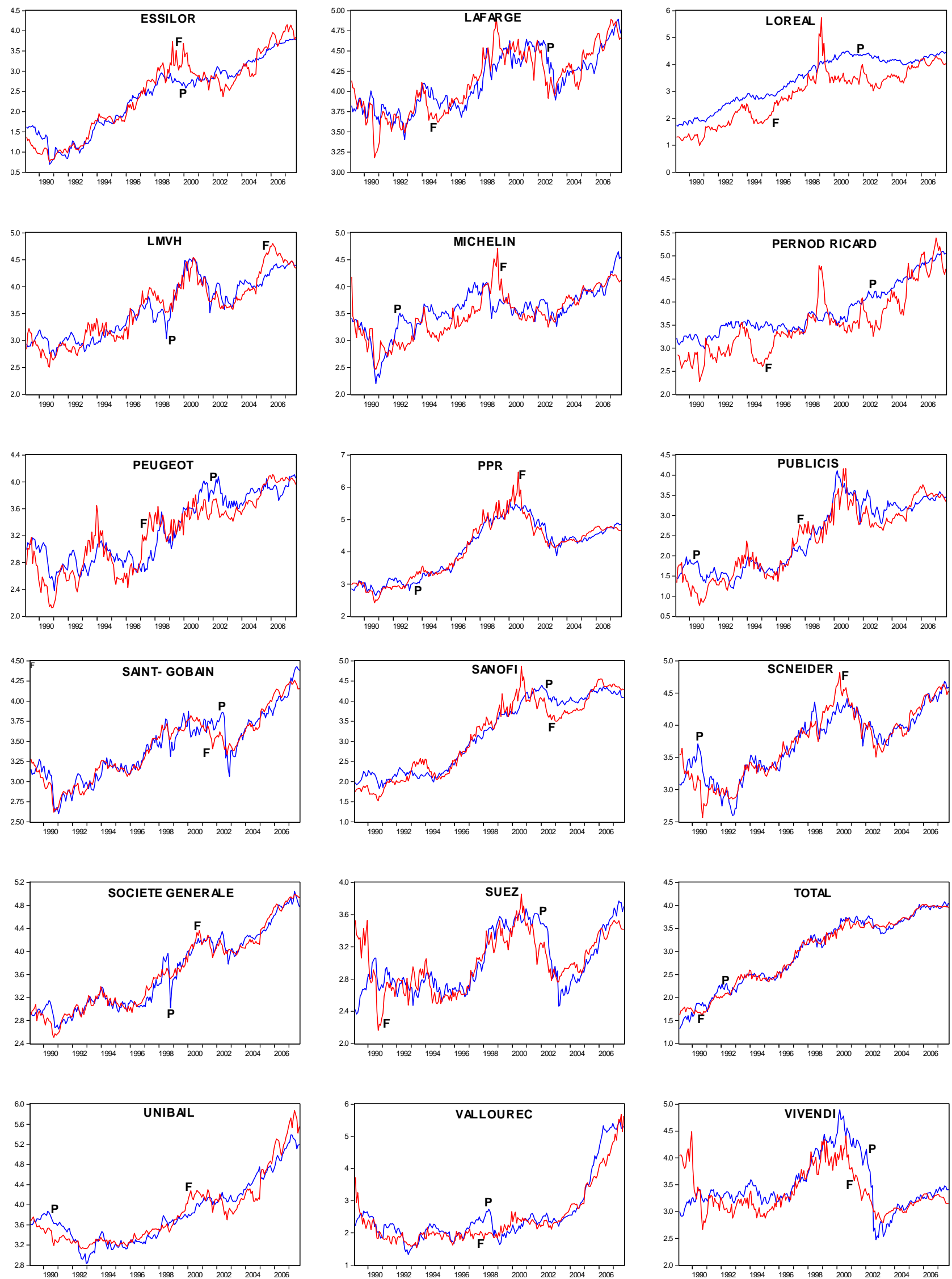

Notes on Figure 3 - for each firm $i$, the figure compares the log of the equity market price $P_{i t}$ with the $\log$ of the fundamental value $F_{i t}^{*}$ estimated according to equation (8). 


\subsection{Equity price adjustment towards fundamental values}

We now focus on the modeling of equity price adjustment toward fundamental values. Let us recall that under the efficient market hypothesis, price equals its fundamental value and deviation corresponds to a white noise, while any dependency in the errors would be an indication of inefficiency if there is no transaction cost. With respect to this debate, it can be seen from the $D W$ statistics in Table 2 that the null hypothesis of no-serial correlation in residuals is rejected for the 27 risk premia equations, implying that the deviations of equity prices from fundamentals are also serially correlated, as can be seen from their time patterns in Figure 4. The average value of the 27 standard-errors in price deviations is $24 \%$, indicating that their magnitudes are substantial, as shown in Figure 4. This suggests that, beyond a possible bias associated with the fundamental value estimation, market friction such as transaction costs (Anderson, 1997) and risky arbitrage due to uncertainty in the measurement of the fundamental value $F_{i t}^{*}$ (Shleifer and Summers, 1990) could generate adjustment delay from equity price to fundamentals. Figure 4 also shows that the dynamics of deviations are characterized by large specific components, ${ }^{29}$ confirming the relevance of considering deviations at firm level rather than at aggregate level. In fact, for a given equity, a market price deviation from its fundamental value represents an opportunity to make arbitrage profits for investors who hold this share in their portfolios. For some investors, deviation may exceed their arbitrage costs (defined as the sum of transaction costs plus a risky arbitrage premium due to uncertainty about fundamental value ${ }^{30}$ ), so they will contribute to a mean-reversion mechanism of the market price towards its fundamental value. For other investors, however, arbitrage costs may be greater than deviation and accordingly disenable them from contributing to this mean-reversion mechanism. Since it is unlikely that the first group will disappear, we may consider that a market force can push the equity price to converge toward its fundamentals at any date, and the larger the first group, the greater the strength of this market adjustment. ${ }^{31}$ Accordingly, based on the simplifying assumption that the relative importance of the two groups of investors is stable over the period, we estimated the following simple linear Error Correction Model (ECM) in a first attempt to check the existence of delayed adjustments and mean-reversion between equity market prices and fundamental values: ${ }^{32}$

\footnotetext{
${ }^{29}$ To appreciate the importance of the disparities of deviations across equities, we evaluated their common component as $\bar{z}_{t}=\frac{1}{27} \sum_{i=1}^{27} z_{i t}$ and computed the $27 R^{2}\left(\bar{z}_{t}, z_{i t}\right)$. The mean value for these coefficients was 0.34, indicating that, on average, about $2 / 3$ of an equity's deviation variance is due to a specific component, while $1 / 3$ is due to a common component. We checked that $\bar{Z}_{t}$ is not correlated with any linear combination of the ${ }_{j} X_{t}$ common factors variables.

${ }^{30}$ The fundamental value of a given equity is supposed common knowledge for stockholders, although each of them has their own appreciation of uncertainty about this value.

${ }_{32}^{31}$ See Jawadi and Prat (2012) for more details.

32 Recall that a simple specification of the ECM can be written as $p_{i t}-p_{i t-1}=\rho_{i}\left(f_{i t-1}^{*}-p_{i t-1}\right)+b_{i}\left(f_{i t}^{*}-f_{i t-1}^{*}\right)+\zeta_{i t}, \rho_{i}>0, b_{i}>0$. Under the long-term equilibrium condition $b_{i}=1$ (meaning that price and fundamental value increase at the same rate) and re-arranging the terms, we get
} 


$$
z_{i t}-z_{i t-1}=-\rho_{i} z_{i t-1}+\sum_{q=1}^{m} a_{i q}\left(z_{i t-q}-z_{i t-q-1}\right)+k_{i}+\zeta_{i t} \quad \rho_{i}>0
$$

where: $z_{i t}=p_{i t}-f_{i t}^{*}$ is the deviation (\%). ${ }^{33}$ It is worth noting that, since (9) is estimated for each of the 27 equities, this approach does not suffer from an aggregation problem resulting from stock price indices wherein some securities are more or less overvalued whilst others are simultaneously more or less undervalued (as can be seen in Figure 4). ${ }^{34}$ In practice, for all of the equities, the longest significant lag is found to be $m=2$ months.

\section{Figure 4 - Equity price deviations}
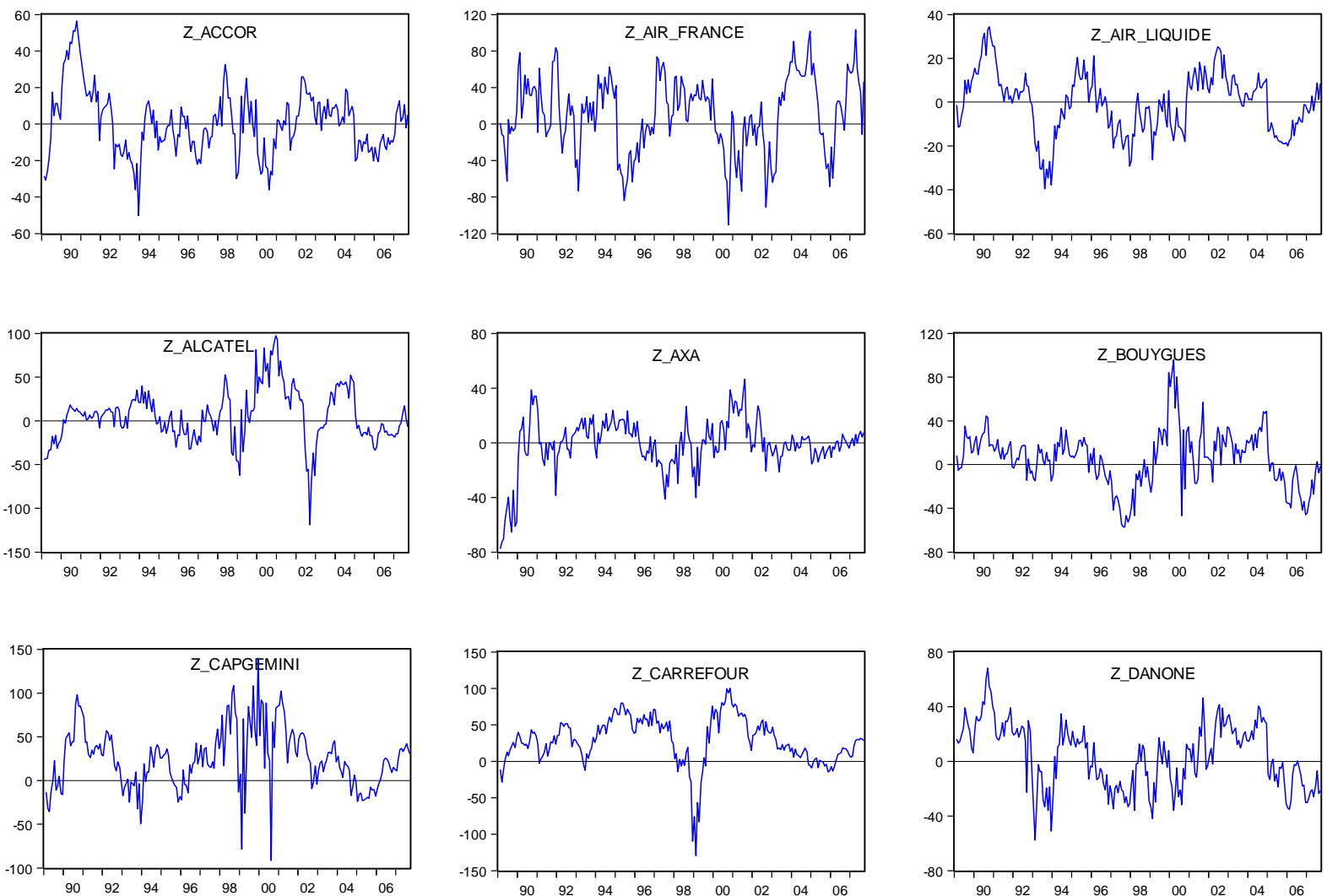

$z_{i t}-z_{i t-1}=-\rho_{i} z_{i t-1}+\zeta_{i t}$. By increasing this simple ECM while including past values of changes in $p_{i t}$ and $f_{t i}^{*}$, we get equation (9) provided that $k_{i}=0$. We leave the possibility that the intercepts $k_{i}$ are different from zero since there is a priori no reason for the means of deviations $z_{i t}$ to be null over the period under consideration. In fact, we found $k_{i} \neq 0$ for only 3 of the 27 equities.

${ }^{33}$ It should be noted that if $z_{i t}$ is viewed as an observable variable, equation (9) corresponds to a classical unit root test, so that the condition $0<\rho_{i}<1$ allows us to conclude that $z_{i t}$ is stationary, meaning that $p_{i t}$ and $f_{i t}^{*}$ are cointegrated. This suggests that $f_{i t}^{*}$ can be considered as a valid measure of the fundamental value. As shown in Table 3, this condition is fulfilled.

${ }^{34}$ These disparities in deviations may suggest that selling overvalued shares and buying undervalued shares can be profitable if the arbitrage costs do not cancel out the expected gains. 

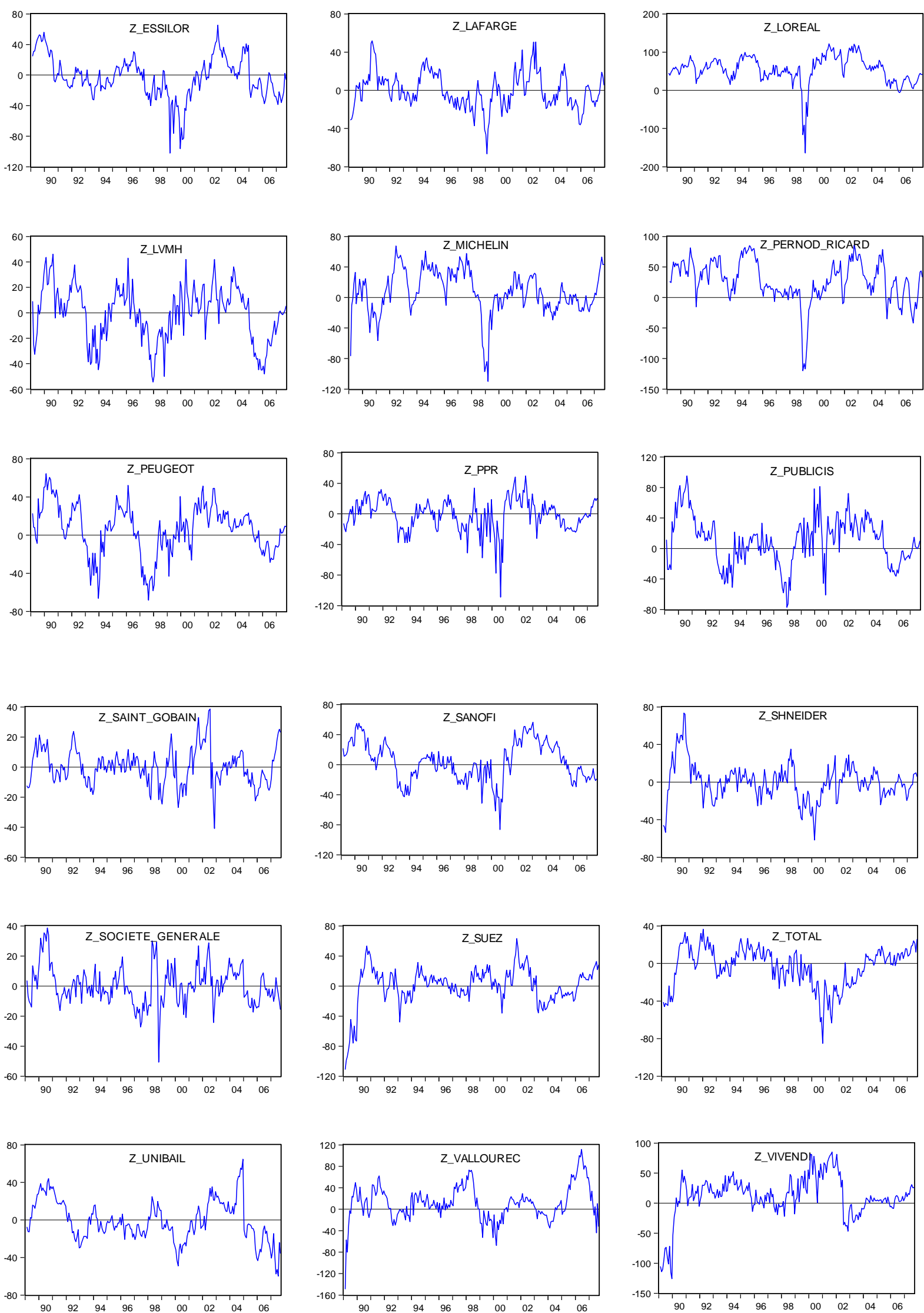

Notes on Figure 4 - for each of the 27 equities, the figure represents the log-deviations $z_{i t}=p_{i t}-f_{i t}^{*}$ (\%) between the market price and the estimated fundamental value. 
In Table 3, we reported the SUR estimates of the ECM system (9) for the 27 equities. Our findings contribute in various interesting points to the field. First, all the coefficients $\rho_{i}$ measuring the strength of the mean-reversion are significantly positive, suggesting the existence of a systematic mechanism for prices to converge toward fundamentals. These results confirm the stationarity of stock price deviation, which reinforces our fundamental value specification in that the latter may be viewed as representing a long-term target. If we put extreme cases to one side, such as those of "Société Générale" and "Saint-Gobain" for the highest values ( $\rho_{i}$ equals 0.27 and 0.24 respectively), and those of "Total" and "Sanofi" for the lowest values ( $\rho_{i}$ equals 0.04 and 0.07 respectively), we can see that the coefficients take fairly similar values for most firms. Second, the residual portmanteau tests for autocorrelation were applied jointly for the 27 equities, giving 221x27 = 5967 number of observations, for lags of up to 4, 8 and 12 months. We found that the p-value for the null hypothesis of this test $\left(\mathrm{H}_{0}\right.$ : no residual autocorrelation) is insignificantly different from zero, thereby rejecting $\mathrm{H}_{0}{ }^{35}$ Third, we checked the distribution of the residuals separately for each equity, while also applying the joint system test. As shown by the p-values in Table 3 for the Skewness, Kurtosis and Jarque-Bera tests, at the $5 \%$ level of significance, residuals exhibit asymmetry (37\% of firms), leptokurtic excess (100\% of firms) and non-normality ( $96 \%$ of firms), suggesting that residuals are heteroskedastic, and this may be viewed as an indication of nonlinearity in the adjustment process.

Table 3 - Error Correction Models for Equity prices

\begin{tabular}{|c|c|c|c|c|c|c|c|c|}
\hline $\begin{array}{l}\text { Estimates } \\
\text { Firms } i\end{array}$ & $\rho_{i}$ & $a_{i 1}$ & $a_{i 2}$ & $f_{i}$ & $\bar{R}^{2}$ & $\begin{array}{c}\text { Skewness } \\
p \text {-value }\end{array}$ & $\begin{array}{l}\text { Kurtosis } \\
\text { p-value }\end{array}$ & $\begin{array}{l}\text { Jarque- } \\
\text { Bera } \\
\text { p-value }\end{array}$ \\
\hline Accor & $\begin{array}{c}0.16 \\
6.2 \\
\end{array}$ & $\begin{array}{l}-0.13 \\
-2.9 \\
\end{array}$ & - & - & 0.11 & 0.45 & 0.00 & 0.00 \\
\hline Air France & $\begin{array}{l}0.15 \\
5.0\end{array}$ & - & - & - & 0.09 & 0.30 & 0.00 & 0.00 \\
\hline Air Liquide & $\begin{array}{l}0.12 \\
5.3\end{array}$ & $\begin{array}{l}-0.13 \\
-3.0\end{array}$ & - & - & 0.08 & 0.00 & 0.00 & 0.00 \\
\hline Alcatel & $\begin{array}{l}0.10 \\
4.2 \\
\end{array}$ & $\begin{array}{l}-0.13 \\
3.0\end{array}$ & - & - & 0.12 & 0.75 & 0.00 & 0.00 \\
\hline Axa & $\begin{array}{l}0.16 \\
5.9 \\
\end{array}$ & $\begin{array}{l}-0.17 \\
-4.1 \\
\end{array}$ & - & - & 0.18 & 0.04 & 0.00 & 0.00 \\
\hline Bouygues & $\begin{array}{l}0.13 \\
5.5\end{array}$ & $\begin{array}{l}-0.15 \\
-4.1\end{array}$ & - & - & 0.16 & 0.47 & 0.00 & 0.00 \\
\hline Capgémini & $\begin{array}{l}0.10 \\
4.6\end{array}$ & $\begin{array}{l}-0.24 \\
7.0\end{array}$ & - & - & 0.24 & 0.48 & 0.00 & 0.00 \\
\hline Carrefour & $\begin{array}{l}0.10 \\
6.0 \\
\end{array}$ & $\begin{array}{l}-0.12 \\
3.2 \\
\end{array}$ & $\begin{array}{l}-0.18 \\
-4.8 \\
\end{array}$ & $\begin{array}{l}1.77 \\
2.4 \\
\end{array}$ & 0.21 & 0.05 & 0.00 & 0.00 \\
\hline
\end{tabular}

\footnotetext{
${ }^{35}$ To save space, we do not report the results of this test. They are however available upon request.
} 


\begin{tabular}{|c|c|c|c|c|c|c|c|c|}
\hline Danone & $\begin{array}{l}0.12 \\
6.5\end{array}$ & $\begin{array}{l}-0.11 \\
-3.8\end{array}$ & - & - & 0.10 & 0.00 & 0.00 & 0.00 \\
\hline Essilor & $\begin{array}{l}0.13 \\
6.2 \\
\end{array}$ & $\begin{array}{l}-0.08 \\
-1.9 \\
\end{array}$ & - & - & 0.08 & 0.00 & 0.00 & 0.00 \\
\hline Lafarge & $\begin{array}{l}0.14 \\
6.7\end{array}$ & $\begin{array}{l}-0.09 \\
-2.9\end{array}$ & - & - & 0.09 & 0.09 & 0.00 & 0.00 \\
\hline L'Oreal & $\begin{array}{l}0.12 \\
6.9\end{array}$ & $\begin{array}{l}-0.10 \\
-3.0\end{array}$ & $\begin{array}{l}-0.16 \\
-5.2\end{array}$ & $\begin{array}{l}-5.11 \\
-4.5\end{array}$ & 0.20 & 0.00 & 0.00 & 0.00 \\
\hline LVMH & $\begin{array}{l}0.15 \\
6.0\end{array}$ & $\begin{array}{l}-0.09 \\
-2.2\end{array}$ & $\begin{array}{l}-0.08 \\
-2.1\end{array}$ & - & 0.12 & 0.85 & 0.00 & 0.00 \\
\hline Michelin & $\begin{array}{l}0.14 \\
6.8 \\
\end{array}$ & - & - & - & 0.07 & 0.02 & 0.00 & 0.00 \\
\hline $\begin{array}{l}\text { Pernod } \\
\text { Ricard }\end{array}$ & $\begin{array}{l}0.09 \\
6.4 \\
\end{array}$ & - & - & - & 0.03 & 0.72 & 0.00 & 0.00 \\
\hline Peugeot & $\begin{array}{l}0.11 \\
6.03 \\
\end{array}$ & $\begin{array}{l}-0.13 \\
-3.6\end{array}$ & - & - & 0.11 & 0.63 & 0.00 & 0.01 \\
\hline PPR & $\begin{array}{c}0.17 \\
6.1 \\
\end{array}$ & $\begin{array}{l}-0.17 \\
-5.0 \\
\end{array}$ & - & - & 0.21 & 0.34 & 0.03 & 0.06 \\
\hline Publicis & $\begin{array}{c}0.12 \\
6.1\end{array}$ & $\begin{array}{l}-0.18 \\
-5.6\end{array}$ & - & - & 0.17 & 0.03 & 0.00 & 0.00 \\
\hline $\begin{array}{l}\text { Saint } \\
\text { Gobain }\end{array}$ & $\begin{array}{c}0.24 \\
8.1 \\
\end{array}$ & - & - & - & 0.12 & 0.13 & 0.01 & 0.01 \\
\hline Sanofi & $\begin{array}{l}0.07 \\
4.1 \\
\end{array}$ & $\begin{array}{l}-0.12 \\
-3.1\end{array}$ & - & - & 0.09 & 0.03 & 0.00 & 0.00 \\
\hline Schneider & $\begin{array}{l}0.14 \\
5.6 \\
\end{array}$ & $\begin{array}{l}-0.07 \\
-1.8 \\
\end{array}$ & $\begin{array}{l}-0.06 \\
-1.7 \\
\end{array}$ & - & 0.12 & 0.00 & 0.00 & 0.00 \\
\hline $\begin{array}{l}\text { Société } \\
\text { Gégérale }\end{array}$ & $\begin{array}{l}0.27 \\
8.1 \\
\end{array}$ & - & - & - & 0.15 & 0.26 & 0.00 & 0.00 \\
\hline Suez & $\begin{array}{l}0.12 \\
7.0 \\
\end{array}$ & - & - & - & 0.10 & 0.50 & 0.00 & 0.00 \\
\hline Total & $\begin{array}{l}0.04 \\
2.0 \\
\end{array}$ & $\begin{array}{l}-0.16 \\
-3.7 \\
\end{array}$ & $\begin{array}{l}-0.12 \\
-3.0 \\
\end{array}$ & - & 0.10 & 0.86 & 0.00 & 0.00 \\
\hline Unibail & $\begin{array}{l}0.10 \\
4.8 \\
\end{array}$ & $\begin{array}{l}-0.08 \\
-1.9 \\
\end{array}$ & - & - & 0.04 & 0.07 & 0.00 & 0.00 \\
\hline Vallourec & $\begin{array}{l}0.11 \\
4.3 \\
\end{array}$ & $\begin{array}{l}-0.13 \\
-2.4 \\
\end{array}$ & $\begin{array}{l}-0.09 \\
-2.0 \\
\end{array}$ & $\begin{array}{l}2.26 \\
2.6 \\
\end{array}$ & 0.14 & 0.00 & 0.00 & 0.00 \\
\hline Vivendi & $\begin{array}{l}0.09 \\
5.6 \\
\end{array}$ & $\begin{array}{l}-0.13 \\
-3.8 \\
\end{array}$ & - & - & 0.12 & 0.00 & 0.00 & 0.00 \\
\hline $\begin{array}{l}\text { Joint test } \\
\text { (p-value) }\end{array}$ & & & & & & 0.00 & 0.00 & 0.00 \\
\hline
\end{tabular}

Notes on Table 3 - for the 27 equities, the table gives the estimates of equation (9) $z_{i t}-z_{i t-1}=-\rho_{i} z_{i t-1}+\sum_{q=1}^{m} a_{i q}\left(z_{i t-i}-z_{i t-q-1}\right)+k_{i}+\zeta_{i t}$ using the Seemingly Unrelated Regression method; the $t$ statistics of estimates are in italics. The acronym “_” indicates that the variable was found to be insignificant and then ultimately dropped from the regression. Skewness test $(\mathrm{Ho}=0)$, Kurtosis test $(\mathrm{Ho}=3)$ and normality Jarque-Bera test (Ho: Skewness $=0$ and Kurtosis=3): if $p$-values $<0.05$, Ho is rejected. 
Overall, this attempt to reproduce the short term adjustment process of share prices toward their fundamental values provides two main findings. On the one hand, individual stock prices are significantly mean-reverting, giving further credence to our mixed approach to estimate fundamental values. On the other hand, the rather low values of the adjusted Rsquared of the linear ECM, the autocorrelation of residuals, and their asymmetry and leptokurtic distribution suggest that it might be advisable to modify the specification of the fundamental value and/or that of the ECM. Concerning the fundamental value estimation, it is of course inherent to the APT that the selection of common factors can be completed since this set is not specified a priori by the theory. However, in so far as the seven common factors retained are in accordance with those repeatedly found in the literature on APT, the hypothesis of missing factors is perhaps not the most likely explanation, although the time stability hypothesis of parameters associated with the seven retained factors could of course be queried. In fact, some variants we made in the set of common factors of risk premia reinforce the idea that misspecification in the fundamental value is probably not the main reason for the statistical properties of deviations. As for the second explanation, a nonlinear ECM could be used to try to describe the adjustment of prices to fundamentals, as some authors have done at aggregate level with stock price indices. ${ }^{36}$ Such a sophisticated process, according to which the strength of the mean-reversion depends on the importance of the deviation, could capture variability in the percentage of investors for whom arbitrage costs are greater or lower than their expected arbitrage profit. This could offer an interesting field of research, consisting of replacing the linear EMC by an STECM (Smooth Transition Error Correction Model), as for example Jawadi and Prat (2012) did for the G7 stock market indices. However, with our individual equities linked to common factors, the STECMs should be estimated simultaneously as a system for the 27 equities (i.e. a Vector STECM). With respect to this, and in line with Teräsvirta (1994) and Van Dijk et al. (2002), it should be noted that Teräsvirta and Yang (2014) very recently gave a solution that could make this research programme possible, since the authors put forward a method to estimate a VSTAR (Vector Smooth Transition Autoregressive Model) that can be adapted to a Vector STECM.

\section{Conclusion}

Using a sample of 27 main equities belonging to the French CAC40 stock index, this paper proposes mixing the dividend discount model (DDM) with arbitrage pricing theory (APT) to determine the fundamental values. While the DDM formula gives the general equity valuation relationship, the APT allows the risk premium included in the DDM formula to be determined, assuming that long-term investors hold efficient portfolios. As a result, the fundamental values issued from the DDM-APT approach describe both trends and major fluctuations in equity prices, the magnitude of fluctuations of these two variables being relatively comparable. This result contrasts sharply with previous related literature devoted to aggregated stock indices, according to which the DDM fundamental values are considerably

\footnotetext{
${ }^{36}$ Moreover, the short-term adjustment process could also involve variables other than those considered in equation (9).
} 
smoothed compared to stock market prices. However, as in studies based on stock price indices, our results arising from a simple linear error correction model (ECM) suggest that individual equity prices still tend to adjust to their fundamental values. This is particularly interesting given that individual equities do not suffer from an aggregation bias. Nevertheless, the residuals of the linear ECM under consideration do not appear to have good statistical properties, suggesting a misspecification in this adjustment process. The extension of the adjustment process to a nonlinear ECM will be at the center of a new research programme.

\section{References}

Abou A., Prat G. (2010), “The dynamics of U.S. equity premia: lessons from professionals' view”, Bankers, Markets and Investors, 104, 4-20

Abou A., Prat G. (2000), Modelling stock price expectations: lessons from microdata, in Price Expectations in Goods and Financial Markets, F. Gardes and G. Prat Eds., Edward Elgar, 31346

Allen D. E., Yang W. (2001), “Do UK stock prices deviate from fundamentals?”, Joondalup Campus Working Paper No. 6027, Edith Cowan University, Australia

Anderson H.M. (1997), “Transaction costs and nonlinear adjustment towards equilibrium in the US treasury bill markets”, Oxford Bulletin of Economics and Statistics, 59, 465-484

Barberis N., Shleifer, A, Vishny, R. W. (1998), “A model of investor sentiment”, Journal of Financial Economics, 49, 307-43

Barberis N., Thaler, R. H. (2003), “A survey of behavioral finance”, in Handbook of the Economics of Finance, G. M. Constantinides, M. Harris and R. Stultz (Eds), Elsevier Science, North Holland, Amsterdam, 1053-123

Barucci E. (2003), Financial markets theory, Springer

Bates, G. E. (1962), “Comprehensive stock value tables”, Harvard Business Review, 40(1)

Beltratti A., Shiller, R. (1990), "Stock Prices and Bond Yields: Can Their Co-movements Be Explained in Terms of Present Value Models?” NBER Working Paper No. 3464, October

Boswijk H. P., Hommes, C. H., Manzan, S. (2007). "Behavioral heterogeneity in stock prices”, Journal of Economic Dynamic and Control, 31 (6), 1938-70

Booth L. (1998), “A new model for estimating risk premiums (along with some evidence of their decline)”, Journal of Applied Corporate Finance, 11 (1), spring, 109-21

Campbell J., Shiller R. (1988), “Stock Prices, Earnings and Expected Dividends", Journal of Finance, July, 43: 662-76

Campbell J. Y., Shiller, R. (2001), "Valuation ratios and the long-run stock market outlook: an update”, NBER Working Paper No. 8282 
Cecchetti S. G., Lam, P. S. and Mark, N. C. (1990), "Mean reversion in equilibrium asset prices”, American Economic Review, 80, 398-418

Cechetti S. G., Lam P. S., Mark N. C. (2000), “Asset pricing with distorted beliefs: are equity returns too good to be true?”, American economic Review, 80, 787-805

Chen N. F., Roll R., Ross S. (1986), "Economic forces and the stock market: testing the APT and alternative asset pricing theories”, Journal of Business, 59, 383-403

Daniel, K., Hirshleifer D., Subrahmanyam A. (1998), "Investor psychology and security market under- and overreactions”, The Journal of Finance, 53, 1839-85

De Grauwe P., Grimaldi M. (2006), "Heterogeneity of agents, transaction costs and the exchange rate”, Journal of Economic Dynamics and Control, 29, 691-719

Elton E. J., Gruber M. J., Mei J. (1994), “Cost of capital using arbitrage pricing theory: a case study of nine New York utilities”, Financial Markets, Institutions and Instruments, 3, 46-73

Efthimios G. D., Norman C. S., Martin W. (2004), "What Valuation Models Do Analysts Use?”, Accounting Horizons, 18(4), 221-40

Fama E. F. (1965), “The Behaviour of Stock Market Prices”, Journal of Business, 38(1), 31105

Fama E. F., French, K. R. (1988), “Dividends yields and expected stock returns”, Journal of Financial Economics, (1), 3-25

Fama E. F., French K. R. (2002), “The equity premium”, Journal of Finance, 57 (2), 637-59

Fontaine P. (1987), “Arbitrage et évaluation internationale des actifs financiers”,Economica, Paris.

Foerster S. R, Sapp S. G. (2005), "The Dividend Discount Model in the Long-Run: A Clinical Study”, Journal of Applied Finance, Vol. 15, N², 55-75.

Gordon M. J. (1959), "Dividends, Earnings and Stock Prices." Review of Economics and Statistics, The MIT Press, 41(2), 99-105

Gordon M. J. (1962), The investment, financing and valuation of the corporation, Irwin, Homewood, Illinois

Gordon M. J, Shapiro E. (1956), "Capital Equipment Analysis: The Required Rate of Profit," Management Science, 3(1), 102-10

Heaton J., Lucas, D. (2000), "Stock Prices and Fundamentals," NBER Chapters, in: NBER Macroeconomics Annual, Vol. 14, 213-64, National Bureau of Economic Research, Inc.

Jawadi F., Prat G. (2012), “Arbitrage costs and nonlinear stock price adjustment in the G7 Countries”, Applied Economics, 44 (12), 1561-82 
Kocherlakota N. R. (1996), “The equity premium: It's still a puzzle”, Journal of Economic Literature, 34, 42-71

Kryzanowski L., Lalancette S., To M. C. (1997), "Performance attribution using an APT with pre-specified macrofactors and time-varying risk premia and betas", Journal of Financial and Quantitative Analysis, 32(2), 205-24

Lorie J. H., Hamilton M. T. (1973), The stock market: theory and evidence, Irwin, Homewood, Illinois

Lucas R. E. (1978), Asset prices in an exchange economy, Econometrica, 46, 1429-45

Malkiel B. G., Cragg J. G. (1970), "Expectations and structure of share prices", American Economic Review, 60, 601-17. This text was updated in (same title), a National Bureau of Economic Research Monograph, 1982

Manzan S. (2003), Essays on nonlinear economic dynamics, PhD Thesis, University of Amsterdam

Mehra R., Prescott E. (1985) “The equity premium: a puzzle”, Journal of Monetary Economics, 15, 145-61

Park C. (2006), "Rational beliefs or distorted beliefs: equity premium puzzle and micro survey data”, Southern economic Journal, 72, 677-89

Poterba J. M., Summers L. H. (1988), "Mean reversion in stock prices: evidence and implications”, Journal of Financial Economics 22, 27-59

Prat G. (1992), Anticipations et évaluation des actions, in "Monnaie, taux d'intérêt et anticipations”, H. Kempf and W. Marois Eds, Economica, Paris, France

Prat G. (2007), “Les comportements boursiers sont-ils eulériens?”, Revue Economique, 58(2), 427-53

Prat G. (2013), “Equity risk premium and time horizon: What do the U.S. secular data say?”, Economic Modelling, Vol. 34, August,76-88

Roll R., Ross R. A. (1980), “An empirical investigation of the Arbitrage Pricing Theory”, Journal of Finance, 35, 1073-103

Ross S. (1976), “The Arbitrage Pricing Theory of capital asset pricing”, Journal of Economic Theory, 13, 341-60

Samuelson P. (1965), « Proof that properly anticipated prices fluctuate randomly”, Industrial Management Review, 6, 41-9

Sharpe W. F. (1964), “ Capital asset prices: A theory of market equilibrium under conditions of risk”, Journal of Finance, 19 (3), 425-42 
Shiller R. J. (1981), "Do stock prices move too much to be justified by subsequent changes in dividends?”, American economic Review, 7, 421-36

Shiller R . J. (2000), “Irrational Exuberance”, Princeton University, March.

Shleifer A., Summers L. H. (1990), "The noise trader approach to finance”, Journal of Economic Perspectives, 4, 19-33

Summers L. H. (1986), “Does the stock market rationally reflect fundamental values?”, The Journal of Finance, XLI, 591-601

Teräsvirta T. (1994), "Specification, estimation and evaluation of smooth transition autoregressive models”, Journal of the American Statistical Association, 89, 208-18

Teräsvirta T., Yang Y. (2014), "Specification, Estimation and Evaluation of Vector Smooth Transition Autoregressive Models with Applications”, CREATES Research Papers, Institut for Økonomi, Aarhus Universitet, 28 March, 44 p.

Van Dijk D., Teräsvirta T., Franses, P. H. (2002), "Smooth transition autoregressive models a survey of recent developments”, Econometric Reviews, 21, 1-47

Welch I. (2000), "Views of financial Economists on the equity premium and on professional controversies”, Journal of Business, 73(4), 501-37

Whitbeck V. S., Kisor M. (1963), “A new tool in investment decision-making, Financial Analysts Journal, May-June, 55-62.

Williams J. B. (1938), Theory of investment value, North Holland Publishing CO, Amsterdam. See Chapter V: "Evaluation by the rule of present worth", 55-75. 